\title{
Forte en Verdedigingswerke op die Kaapse Oosgrens 1806-1836
}

\author{
Mnr P.J. Bezuidenhoud*
}

This article deals with fortresses and defensive works on the Cape eastern border during the period 1806 to 1836 describing not only the appearance and floorplans of the fortresses but what gave rise to their coming into existence and what role they fulfilled in the historical events of the time.

\section{Hoofstuk I Wat is forte en verdedigingswerke?}

Fortifikasie kan gedefinieer word as die militêre kuns om sekere strategiese plekke te versterk teen 'n aanval. Dié woord word afgelei van die Latynse woord fortis wat beteken sterk en facere wat beteken om te maak of te bou en impliseer die bou van versterkte verdedigings. ${ }^{1}$ By wyse van ' $n$ eenvoudige voorbeeld, kan dit as volg geilllustreer word:

Indien ' $n$ seun agter ' $n$ heining wegkruip as sy maat hom met kluite bestook, trek hy net tydelike voordeel uit die situasie. Maar as hy ' $n$ ondeurdringbare voorwerp tussen hom en sy "vyand" plaas en daaragter skuil, dan het hy ' $n$ fortifikasie gebou. $^{2}$

Fortifikasie bestaan uit twee elemente, naamlik beskerming en hindernis. Dit verleen beskerming teen die vyand se skietgoed en die hindernis keer dat die vyand nie te naby kom nie dus vertraag hom onder vuur. ${ }^{3}$

Die beskermingsaspek kan direk of indirek wees. Direkte beskerming kan wees met behulp van 'n muur, sterk genoeg om vyandelike wapens te keer, dog dit bring mee dat die verdediger homself moet vertoon, tensy skietgate wat klein genoeg is, aangebring word, en 'n geweer daardeur pas. Hierby moet gewaak word dat die verdedigers se skootsvak nie belemmer word nie. $^{4}$

Indirekte beskerming is wanneer die vyand nie baie naby kan kom om skade aan te rig nie, byvoorbeeld 'n hoë muur op 'n krans. Die militêre pos Retief herinner ons sterk hieraan. 'n Ander vorm van indirekte beskerming is versteking van die fortifikasie. ${ }^{5}$

'n Hindernis kan bestaan uit enigiets wat die vyand se aantog kan stuit of vertraag - byvoorbeeld ' $n$ vol rivier, droë sloot, digte doringbosse of 'n groot oop stuk grond. 'n Kombinasie van die voorafgaande sal meer effektief wees. Die vereiste is natuurlik dat die verdedigers in staat moet wees om die hindernis te verdedig vanuit hulle verdedigende posisie, anders kan dit ingeneem of vernietig word. ${ }^{6}$

Verdediging moet hoofsaaklik opgestel word volgens hóé die vyand gaan aanval en van watter wapens hy gebruik sal maak. Die hindernis aan die ander kant moet van so 'n aard wees, dat die beste effek met die verdediger se wapens verkry kan word. ${ }^{7}$

Die probleme van die ingenieur, of wie ook al verantwoordelik is vir die bou van die fort, is om ' $n$ waardasie te maak en al die voorwaardes van die probleem te harmonieer, soos byvoorbeeld, soort wapens wat gebruik gaan word, hoe die onmiddellike omgewing lyk, die beskikbaarheid van boumateriaal, strategiese moontlikhede en die koste van oprigting daaraan verbonde. ${ }^{8}$

Fortifikasies word gewoonlik in twee soorte verdeel, naamlik permanente- en veldfortifikasies.

Permanente forte word tydsaam met al die beskikbare materiaal wat die land kan oplewer, asook bou- en meganiese vernuf gebou, met materiaal wat duursaam is en wat die toets van die tyd en aanslae sal verduur. ${ }^{9}$

Veld- of tydelike fortifikasies word gebou deur die troepe self in die veld, miskien gehelp deur plaaslike arbeid, terwyl beskikbare gereedskap gebruik moet word, met materiaal wat nie baie voorbereiding nodig het nie, soos grond, bome, struike, ligte plante en los klip. ${ }^{10}$

Tussen bogenoemde twee vind ons nog semipermanente fortifikasies. Dit word gevind met 'n kampanje waar dit gebruik word vir beskerming; gebou so na as moontlik aan 'n permanente verdediging, wat in die kortste moontlike tyd op- 
gerig word, met voldoende beskikbaarheid van materiaal en opgeleide burgerlike arbeid. ${ }^{11}$

Die doel en funksies van fortifikasie is veelvuldig. In Ninevé en Babilon, word die hele bevolking in tye van oorlog beskerm, behalwe die leër en huishoudelike goedere. Die Middeleeuse feodale landhere het kastele gebou vir sekuriteit, om aanvalle van bure af te slaan; dit het waggehou oor dorpe, brûe en mere, in ruil waarvoor die landheer belasting ontvang het. Ook is welgestelde dorpe met mure omring om mense en eiendom te beskerm. ${ }^{12}$

Strategiese forte, waaroor hierdie artikel hoofsaaklik handel, is opgerig om riviere, driwwe, spoorlyne, militêre magasyne, belangrike paaie, ponte en oorgange oor berge te beskerm. ${ }^{13}$

Versperde forte is nodig in ' $n$ land as die nodige kommunikasielyn nie verander kan word nie. Dit moet byvoorbeeld vir die vyand nodig wees om eers die fort te oorrompel voordat hy verder kan gaan. Indien daar slegs een rigting is waaruit die fort benader kan word, is sy ligging goed - veral as kanonne beskikbaar is. ${ }^{14}$ In hierdie tema sal ons in die laaste hoofstuk ' $n$ evaluering maak om te sien of die forte en fortifikasies aan die Kaapse Oosgrens aan al bogenoemde vereistes voldoen om hulle sodoende geslaagd te maak. ${ }^{15}$

\section{Hoofstuk II Inleiding tot die tema}

Lank voor 1806 het die blankes en swartes by die Visrivier kontak gemaak met mekaar. Die grondoorsaak word genoem die "groot honger", waar die witman gekeer is deur die uitbreiding van die swartes na die suidpunt van Afrika, terwyl massas swartes verder noordwaarts strek. ${ }^{16}$

Hierdie botsende ideologieë, van kontak tussen beskawing en barbarisme, het verreikende gevolge gehad in die Suid-Afrikaanse geskiedenis en dit kan dan ook tereg genoem word as een van die belangrikste tydvakke. Die grens was eintlik slegs ' $n$ vae gedagte in die regering se koppe, aangesien verdediging en bestaan omtrent onmoontlik was. Die dunverspreide wit bevolking was gewoond aan uitbreiding om nuwe weivelde te soek; so ook die swartes wat met beeste geboer het. ${ }^{17}$

Die blankes wou 'n geordende samelewing skep en hulleself in 'n hegter eenheid saamsnoer. Die regering was ver en het vir alle praktiese doeleindes nie aan die oosgrens bestaan nie. Veld- kornette en kommandante het gesag gevoer in die grensdistrikte en hulle het nie geglo in die regering wat buitendien onpraktiese wette gehad het nie. ${ }^{18}$ ' $n$ Wet het gewoonlik twee aspekte gehad - beperking en beskerming. Die koloniste het geglo dat slegs die eerste een van toepassing was. $^{19}$

Ook het die swartes 'n probleem gehad met die ekonomiese aspek, veral as gevolg van hul tradisies. Hulle was meer primitief en bly nie op een plek nie. 'n Grens was vir hulle 'n vae begrip, waar die blankes meer glo in eienaarskap. As stamgebonde mense was hulle gevaarlike bure om 'n swak verdedigde grens. Dit het veediefstalle veroorsaak - as hulle nie grondgebied kon kry nie, steel hulle dan maar beeste om te vergoed. ${ }^{20}$

Daar is heelwat geskryf oor dié twee uiteenlopende groepe, gesien uit verskillende oogpunte. Die pro-naturelle filantrope en sendelinge vertel baie van die onreg van die blankes teenoor die swartes, van die vraterige blankes (vee afneem) en onsimpatieke behandeling. Ander persone praat van die swartes as diewe, oneerlik, onbetroubaar en slu. Hulle beweer dat die oosgrensman swaargekry het met die naturelle, baie is selfs geruïneer, asook 'n regering wat kant kies vir die swartes. ${ }^{21}$

Om die ontwikkeling van die oosgrens te verstaan moet 'n mens die primêre oorsaak tussen blank en nie-blank se misverstand, naamlik die enorme uiteenlopende verskille en lewensuitkyke, gewoontes en gebruike bestudeer. In 1806 was die grens van die oostelike distrikte die Visrivier, en die regering het die koloniste verbied om oor te gaan na die naturellegebied van die Amaxhosa. ${ }^{22}$ Die oostelike provinsie was in die eerste stadium van ontwikkeling. Die afwesigheid van sosiale gemeenskappe, die gebrek aan onderwysinrigtings en die harde lewe, bring dapperheid, uithouvermoë en die strewe om selfbehoud aan die kant van die boere na vore. ${ }^{23}$

Twee aspekte wat na my mening tuishoort in die konteks van die onderwerp, is die aandeel van die burgers om 'n oplossing te probeer vind vir hul selfbehoud, naamlik gefortifiseerde plaashuise en deelname deur middel van kommando's. Voorbeelde van eersgenoemde is die volgende:

Een van die mooiste en beste versterkte woonhuise was Barville Park en is in 1830 deur Stephen Dell gebou. Die huis was omring deur 'n 
klipmuur met loergate en uitkykposte op die hoeke. Hierdie plaas ten suide van Port Alfred, met sy dubbelverdieping woonhuis en dik mure, sou egter 'n waterprobleem ondervind gedurende ' $n$ langdurige belegging. Binne die ringmuur kon groot hoeveelhede beeste en skape beskerm word en van die buitegeboue is omskep in store vir ammunisie en ander voorrade. ${ }^{24}$

Septon Manor is geleë sewe myl van Fort Beaufort op die Adelaide pad. Dis in 1835 opgerig deur George Gilbert, nadat die oorspronklike woning in die Oorlog van die Byl verwoes is. Behalwe dat al die geboue ommuur was, het hierdie enkelvlak woning ook loergate gehad wat van binne met luike toegemaak is. ${ }^{25}$

Sidbury, gebou in 1828 deur die afgetrede luitenant Daniell van die Royal Navy, lyk net soos Barville Park. Lombardspos, naby Southwell, sal later in 'n ander hoofstuk ook 'n rol speel. Hierdie gefortifiseerde dubbelverdieping plaashuis van klip met geboue aan al vier kante, het die besondere eienskap gehad dat daar geen deure of vensters op die grondverdieping was nie - met loergate op die eerste verdieping. Sy dik mure was geensins deurdringbaar nie.. ${ }^{26}$

Die bekende versterkte huis, Hounslow, elf myl van Grahamstad op die Fort Beaufortpad, het ook bestaan uit mure met loer- of skietgate. Dit is later deur Thomas Baines op doek vasgelê. ${ }^{27}$

Addo Drift was een van die bes versterkte woonhuise met skietgate en het sy naam gekry van die Hottentot woord "Ados" wat beteken "pad" of "drif". Teen 1815 was dit nog nie as 'n militêre pos op die militêre kaarte aangedui nie, dog die kaarte van 1818 en 1820 dui aan dat dit permanent in gebruik geneem is. Op Knobel se kaart van 1820 staan die naam Kadow se Drif en is dit beman deur 20 soldate en ' $n$ sersant. ${ }^{28}$

Die Kommandostelsel, wat self deur die boere van die oosgrensdistrikte ontwikkel is, het ontstaan as gevolg van ' $n$ tekort aan geldvoorsiening deur die N.O.I.K. Hulle kon nie soldate op die grens finansier nie. Met die Nederlands en Britse versoenings wat heeltemal onsuksesvol was, asook die geweldige lang grenslyn (800 $\mathrm{myl}$ ), het die boere daartoe oorgegaan om hulle self te organiseer in kommando's. Beheer is uitgeoefen deur kommandante en veldkornette. Dit het veroorsaak dat die boere gedurig hulle plase onbeskermd moes laat om gesteelde vee in Xhosaland te gaan haal. Slegs ' $n$ paar bees- wagters het gewoonlik die vee op die geweldige groot en ylverspreide plase opgepas. ${ }^{29}$ As die boere die gesteelde vee terugneem, vind daar net weer hernude stelery plaas. Dit het groot wrywing veroorsaak wat tot bittere botsings en vele Xhosa-oorloë gelei het. ${ }^{30}$

Daar is toe besef dat om ' $n$ Xhosa-inval in die Kolonie af te weer, permanente fortifikasies by strategiese punte opgerig sal moet word. Oorspronklik is dit by natuurlike driwwe en deur troepe beman. ${ }^{31}$

Stadigaan is permanent forte in ' $n$ lyn gebou om die hele oosgrens te beskerm. Na elke Xhosainval in die Kolonie is hul getalle vermeerder en in die proses het dorpe rondom die forte tot stand gekom, naamlik Grahamstad (1812), Kingwilliamstown (1835), Oos-Londen (1848) en nog vele ander. ${ }^{32}$

Die buiteposte, geplaas in bevelvoerende posisies dwarsoor die hele grensarea, was meestal klipgeboue, baie solied gebou, gewoonlik vierkantig met mure vol skietgate. Elke fort bied akkommodasie vir 'n sekere getal berede soldate en infanterie. Sommige poste was baie geisoleer en hulle garnisoene was dikwels onder groot stremming geplaas weens 'n tekort aan voorrade. $^{33}$

Kommunikasie was besonder moeilik in oorlogstyd, as gevolg van die ondeurdringbare bosse wat die poste omring het - altyd groen sagte plante wat bestand is teen vuur en dus kon dit net gedeeltelik skoongemaak word. Brûe was onbekend en paaie is tussen die poste gekap. ${ }^{34}$

Die toestand was dus naby aan haglik vir die bewoners van die oosgrens onder die vorige regerings. Wat sou die Britte gedurende die tweede Britse besetting doen om die oosgrensprobleme te verlig?

\section{Hoofstuk III \\ Die vierde Xhosa-oorlog - 1812}

Met die tweede Britse besetting van die Kaapkolonie in 1806, loop die spanning besonder hoog 


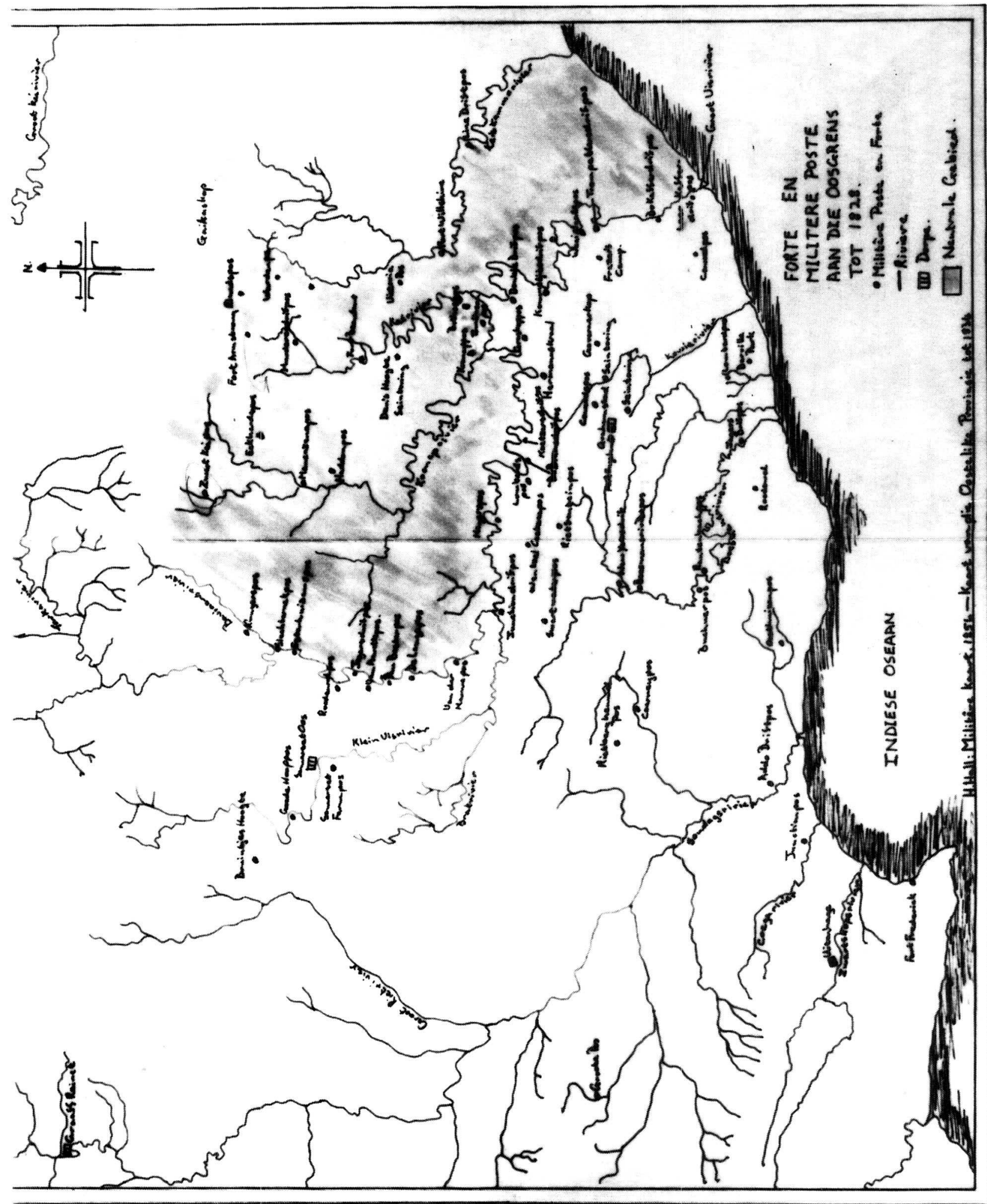


aan die Kaapse oosgrens. Generaal-majoor David Baird, wat as agerende goewerneur vanaf 10 Januarie 1806 tot 17 Januarie 1807 opgetree het, behou die meeste amptenare van die Bataafse Bewind. ${ }^{35}$

Na drie Xhosa-oorloë in 1779, 1789 en 1799, waarvan die Xhosas die eerste twee gewen het, is besluit om verdedigingswerke op te rig. ${ }^{36}$ Die heel eerste militêre pos is dan ook die Starfort (vernoem na die Hope en Star skepe) genoem. Dit is in 1798 opgerig in die oostelike provinsie. In 1799 het hierdie fort 'n hewige aanslag van die swartes en Hottentotte afgeweer. ${ }^{37}$

Kaptein Alberti was op hierdie stadium wel met 'n militêre mag op die grens gevestig, maar die eintlike verdediging van die grens was in die hande van die inwoners van die grens gekonsentreer. By Fort Frederick het hy 'n militêre hoofkwartier tot stand gebring om die oosgrensvraagstukke te koördineer. ${ }^{38}$

'n Uiters belangrike aanstelling van Baird was egter dié van Kaptein Glen Cuyler van die 59ste Regiment in die plek van Kaptein Alberti. ${ }^{39}$ In Cuyler het die Britse regering ' $n$ man gehad wat hom probeer inleef het in die probleme van die grensburger, die swarte verstaan het en self dikwels in botsing met die owerhede gekom het. Nadat hy aanvanklik ook van die omkoopmetode deur middel van presente gebruik gemaak het, het hy algaande sy weg gevind na die enigste praktiese metode. ${ }^{40} \mathrm{Op}$ hierdie stadium wou die blankes en swartes beheer oor die Suurveld verkry.

Gedurende die eerste deel van die tweede Britse besetting, het die Xhosas verder wes beweeg vanaf die Sondagsrivier en krale gestig. Ndlambe, 'n sterk leier van die Xhosas melk die boere van vee en in 1807 ignoreer Cungwa die landdros en veldkornette se bevele en migreer vanaf die Boesmansrivier na die Van Stadensrivier. Ook Habana vestig hom by die Gomkarivier in Oktober 1808. Dit is dus te verstane dat die koloniste hard geraak het teenoor die Xhosas, met geen kompromie. ${ }^{41}$

Teen hierdie agtergrond arriveer Caledon aan die Kaap. Met sy liberale uitkyk, word hy nogtans deur die minister van Kolonies gewaarsku om liewers 'n mooipraatbeleid uit te voer. Ook moet een van die opperhoofde erken word vir onderhandelinge - die keuse val op Gaika, hoof van die Xhosas ten weste van die Keirivier. ${ }^{42}$ Dié keuse was egter verkeerd, want hy was heelwat swakker as Ndlambe, wat ondersteun is deur Hintsa. As gevolg hiervan het die skema misluk. ${ }^{43}$

Op 23 Januarie 1809 versoek Caledon vir majoor Collins om, vergesel van Andries Stockenstrom en dokter Cowdry, 'n besoek aan die Oosgrens te bring en sekere aanbevelings te doen. ${ }^{44}$ Om sy woord gesag te laat dra, word hy aangestel as spesiale kommissaris van Uitenhage en Graaff Reinet. ${ }^{45}$

Die geselskap besoek verskeie hoofmanne in Xhosaland om hulle te probeer oortuig om nie die Visrivier oor te steek nie; en die wat reeds daar woon, oor te haal om die kolonie te verlaat. Hulle slaag egter nie. ${ }^{46}$ Met sy terugkoms dien hy ' $n$ verslag by die goewerneur in en beveel aan dat die Xhosas met geweld oor die Visrivier gedryf moet word en die Suurveld skoongemaak moet word. Ook moet 'n sterk militêre mag oosgrens toe gestuur word en die plase moes verklein word. ${ }^{47}$ Meer koloniste moet op die grens geplaas word om die blanke bevolking te versterk en 'n militêre pos moes iewers opgerig word, vanwaar gereelde verbinding met opperhoofde kon plaasvind. ${ }^{48}$

Aan Kaptein Evatt van die 21ste Light Dragoons word dan ook die taak opgedra om in 1810 by Bruintjes Hoogte 'n militêre pos op te rig om hiérdie taak te vervul. Van Collins se ander voorstelle het niks gekom tydens Caledon se bewindstydperk nie. ${ }^{49}$

Caledon word op 5 September 1811 vervang met Cradock. Hy reageer dadelik op Collins se verslag, aangesien die toestand heelwat versleg het, nadat die landdros van Uitenhage verklaar het dat slegs een plaas oos van sy drosdy nog beset is. ${ }^{50}$ Majoor Cuyler, landdros van Uitenhage, word versoek om dadelik ' $n$ kommando op die been te bring. Hy kon hulp verkry van die garnisoen by Fort Frederick, dog dit was nog nie genoeg nie. ${ }^{51}$

Op 8 Oktober 1811 beveel Cradock dat ook die kommando's van Swellendam, George, Uitenhage en Graaff-Reinet opgeroep moet word. Kolonel Graham word in bevel geplaas van 600 Hottentotte van die Cape Corps - daarby toegevoeg 49 kannoniers, 166 troepe van die 21 ste Light Dragoons, 221 soldate van die 83ste Regiment en drie van sy eie Highlanders, met die duidelike opdrag om alles in sy vermoë te doen om die Xhosas oor die Visrivier te kry. ${ }^{52}$ Daarin slaag hy ongelukkig nie en die Vierde Xhosaoorlog begin. 


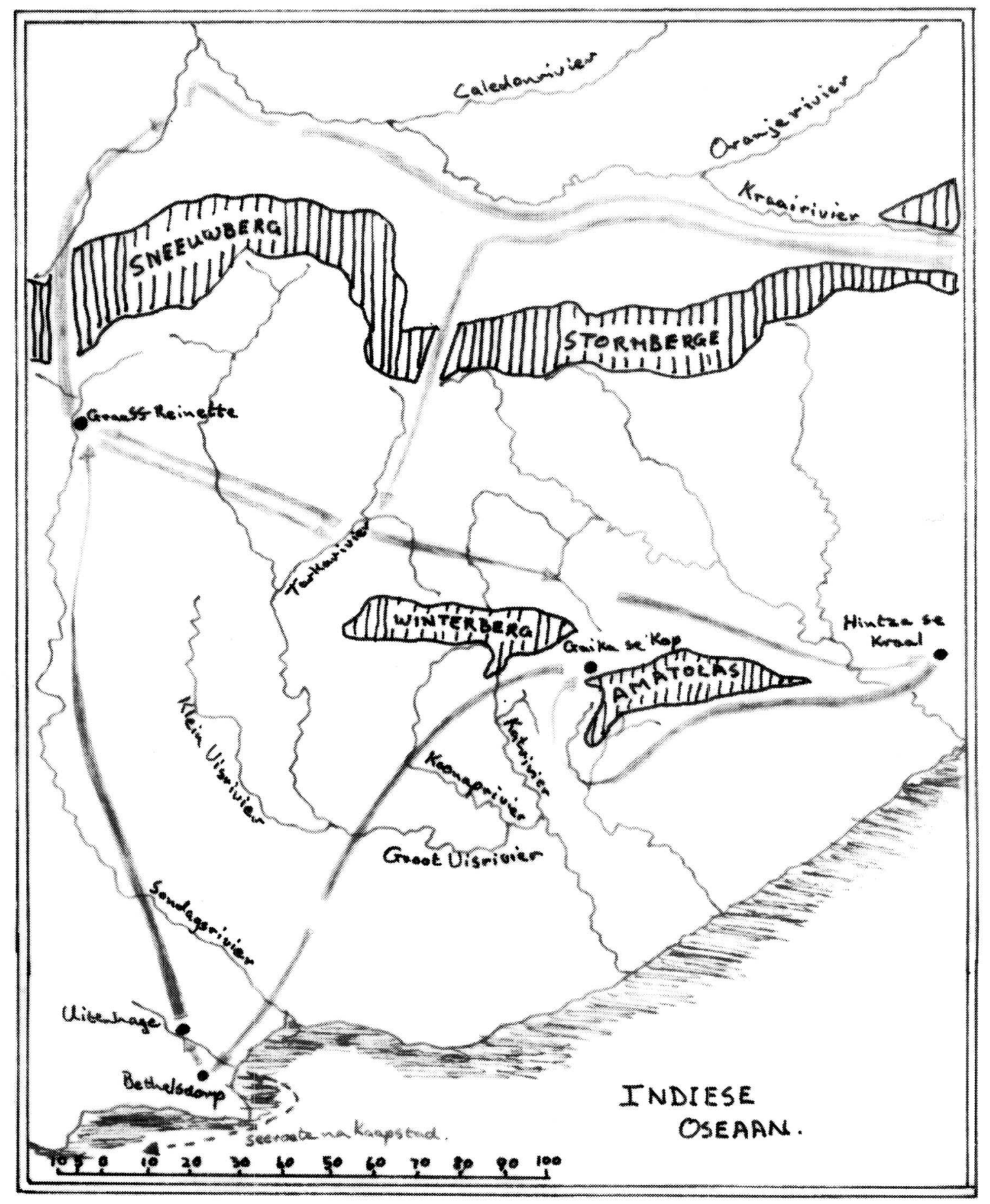

Kolonel Collins se reis in 1809, vergesel deur $A$. Stockenstrom 
Op hierdie stadium is die hele oorlogspoging geadministreer uit die militêre hoofkwartier by Noutoe. ${ }^{53}$ Die kommando's ontmoet by die mond van die Sondagsrivier. Cuyler neem sy mag na Ndlambe se blyplek, wat hom amper sy lewe kos, dog Ndlambe se troepe word weggesteek in die Rietberge. In Desember 1811 lê landdros Stockenstrom by Bruintjes Hoogte besoek af en aan hom word die taak opgedra om die Suurveld skoon te makk in die rigting van die Rietberge, waar hy in 'n opvolg operasie sy lewe verloor. Die gebeurtenis word egter deur sy seun gewreek. $^{54}$

Teen Maart 1812 was die oorlog verby. Cungwa is gedood en Ndlambe met sy volgelinge 'exodus' oor die Visrivier na Xhosaland. Die hele gebied tussen die Sondags- en Visrivier was nou ontruim. ${ }^{55}$ Teen die einde van die oorlog was daar 800 burgers en 1252 Britse en Hottentotsoldate in die veld. ' $n$ Permanente leër was egter buite die kwessie. As alternatief word toe voorgestel om die hele Visrivierarea te fortifiseer. ${ }^{56}$

Voortaan moes plase rondom grensposte uitgereik word, sodat mettertyd 'n kordon digbevolkte poste langs die grens kon ontstaan. As lokmiddel sou geld dat die plase vir 10 jaar kwytgeskeld word van rente. Honderd families het van die aanbod gebruik gemaak. ${ }^{57}$ Ook moes patrollies van 10 man nou gestasioneer word op verskillende plekke. Dit het egter geen vrugte afgewerp nie, want teen April 1812 het die Xhosas weer begin terugstroom na die Kolonie, sonder dat die patrollies hulle sien. Kolonel Graham besluit dus om nou die hele Cape Regiment permanent op die oosgrens te stasioneer. ${ }^{58}$

Hy stel op 14 Augustus 1812 drie militêre poste voor wat met nedersetters omring moet word vir beskerming, nadat hy persoonlik die terreine ondersoek het. Die eerste een was die hoofkwartier van die Cape Regiment op die leenplaas van Lucas Meyer, bo-op 'n hoogliggende tong van die land gevorm deur die Kowierivier en 'n ander stroom wat saamvloei onder die barak. Rondom is 20 tot 30 akkers vir besproeiing en verbouing oopgelaat. Dié plek was $20 \mathrm{myl}$ va die Visrivier en negentig myl van die see. ${ }^{59}$ Hoër op teen die heuwels was ideale weiveld vir beeste en langs die Kowierivier was 10 myl van ideale landbougrond. Daar was ook volop hout, terwyl die paaie redelik was. Dié fort word Fort England genoem. Later het die dorp Grahamstad daar ontstaan. ${ }^{60}$.

By Kasouga op die leenplaas van Piet Lombard, beset deur een kompanie van die Cape Regi- ment kon 10 tot 20 families onderhou word. Dit was $40 \mathrm{myl}$ van die Visrivier en $30 \mathrm{myl}$ van die hoofkwartier geleë en word Lombardspos (lombarad) genoem. ${ }^{61}$

Die derde plek wat Kolonel Graham uitgesoek het, was die leenplaas met die naam Noutoe wat op daardie stadium beset was deur 'n halwe kompanie van die Cape Regiment en familie van veldkornet De Lange. Dit was slegs 7 myl van Fort England. ${ }^{62}$ Verbindingsweë met die hoofkwartier en Bruintjes Hoogte was ook uitstekend. By al drie bogenoemde plekke kon vrugte en groente gekweek word, 'n goeie oes kon elke jaar verseker word en 'n watermeul kon by elkeen opgerig word. ${ }^{63}$

Voor sy vertrek is dit tydelik beman en gee hy instruksies vir die beveiliging daarvan - "Instructions to Commanders of Posts", 30 Maart 1812 Uitenhage. ${ }^{64}$

(Ek verkies om dit graag volledig te verstrek en my motivering hiervoor is dat dit volgens my mening vir die soldaat op die oosgrens van kardinale belang was. Dit het riglyne gegee vir die onervare soldate wat nie altyd vertroud was met die omgewing nie. Ook is dit baie belangrik aangesien die grens op hierdie manier effektief beskerm kon word. Die insig wat Graham op daardie tydstip getoon het, is selfs vandag op die noordgrens van SWA vir die Suid-Afrikaanse soldaat van uiterste belang in die stryd teen die SWAPO-terroriste.)

Die hoofdoel was patrollering van elke ruigte en kloof. Die res word aan die oordeel van die offisiere en troepe oorgelaat om hulle by die onvoorsiene aan te pas. Offisiere moes hulleself op hoogte bring van die omgewing tussen hulle pos en die volgende een. Om verrassing uit te skakel moes die geweer altyd saamgedra word as hulle gaan water haal, want die Xhosas val altyd gedurende die dag aan wanneer niemand dit verwag nie. Geen wit kledingstuk mag gedurende die nag gedra word nie. Indien 'n pos aangeval word moet die soldate sonder ' $n$ geraas en verwarring opstaan en na voorafbepaalde stellings gaan. Niemand vuur tensy hy seker is van die skoot en nooit meer as die helfte van die gewere mag ongelaai wees nie. ${ }^{65}$ Die magte moet verdubbel word gedurende die nag en gedurige wisseling moet plaasvind. Die vyand mag nooit gedurende die nag agtervolg word nie, tensy dit ' $n$ maanligaand is en ' $n$ oop kontrei. Al die bosse in die nabyheid van die poste moet skoongemaak word. Gereelde patrollies moet uitgestuur 
word vanaf elke pos en die sterkte daarvan hang af van die terrein en die hoeveelheid soldate by die pos. Patrollies moet absoluut stil beweeg en gekamoefleer wees. Geen vure mag in die nabyheid van die vyand gemaak word nie. Spore van mense en diere moet deur almal bestudeer word, sodat elkeen gewoond kan raak daaraan. Indien 'n spoor raakgeloop word, maak almal dadelik atent daarop. Volg dit op totdat dit uit die gebied gaan. ${ }^{66}$

Indien die spore weswaarts beweeg, moet die ander poste gewaarsku word sodat hulle 'n hinderlaag kan lê. Indien so 'n berig ontvang word, moet alles in die vermoë gedoen word om die oortreders in te haal. Indien enige soldaat sonder skoene loop, moet hy elke nou en dan 'n kruis op sy spoor maak om te wys dat hy 'n vriend is. Die teken moet voortdurend verander word.

'n Eskort infanterie moet dragonders vergesel as gevaar verwag word. Die families en eiendom van die inwoners van die gebied val onder die soldate se beskerming en hulle moet te alle tye hulp verleen waar nodig blyk. Soldate moet ook help om vee op te pas veral naby die Visrivier. Indien opgemerk word dat vee gesteel is, moet 'n waarskuwing dadelik van pos tot pos in die rigting van die grens gestuur word en 'n sterk poging moet aangewend word om dit terug te kry.

Alle naturelle binne die grense moet as vyande beskou en dienooreenkomstig gehanteer word, behalwe dié wat boodskappe van hulle hoofde dra. Teenoor alle Hottentotte en slawe sonder passe moet opgetree word soos met die Xhosa. $^{67}$

Hierdie instruksies het vir al 22 militêre poste aan die oosgrens gegeld. In die volgende hoofstuk sal ons al die militêre poste wat gedurende die Vierde en Vyfde Xhosa-oorlog gebou is, behandel, aangesien hulle van 1812 tot ongeveer 1822 gegeld het. Hulle het gestrek van die see tot by Bruintjes Hoogte, in 'n semi-sirkel opgerig, sodat hulle almal binne 'n dag in verbinding met die hoofkwartier by Fort England kon kom. ${ }^{68}$ Dit was die latere Grahamstad. ${ }^{69}$

\section{Hoofstuk IV Lord Charles Somerset se bewindstydperk}

Op 5 April 1814 arriveer Somerset as nuwe goewerneur aan die Kaap en erf onmiddellik al die oosgrensprobleme van goewerneur Cradock. ${ }^{70}$
Gedurende hierdie tydvak was die grens betreklik stil, aangesien die Xhosas nog hulle wonde gelek het na die Vierde Xhosa-inval in die Kolonie. Die grenspatrollering was heel effektief, deurdat die militêre poste as afskrikmiddel gedien het,. In 1816 is daar slegs een keer deur 200 soldate van die Cape Corps oor die grens gegaan om 1000 gesteelde beeste terug te bring. Teen 1817 bly daar nog net 6 kompanies Hotentotte oor met 'n majoor, drie sersante vir elke kompanie en twee korporaals. 'n Belangrike verandering was die vervanging van die 72 ste Highlanders met die 21ste Light Dragoons en Royal African Corps. ${ }^{71}$

Gedurende 1814 is ook begin met die bou aan Fort England in die vorm van twee vierkante, terwyl offisiere en onder-offisiere grond rondom die fort ontvang het. Dis vernoem na Kolonel Richard England van die 75ste Regiment (later van die Gordon Highlanders). ${ }^{72}$

Om die vrede op die grens te bewaar, reik Somerset die volgende instruksies uit:

(a) Daar mag geen provokasie in die Xhosas se eie gebied wees nie.

(b) Geen vee van die blankes mag in die naturellegebied wei nie.

(c) Niemand mag oor die Visrivier gaan, tensy gesteelde vee gevolg word.

(d) Indien iemand ' $n$ Xhosa binne die grense van die Kolonie vang, sou hy vyf riksdaalders betaal word, terwyl een riksdaalder vir ' $n$ bees betaal is wat teruggebring word. ${ }^{73}$

Hierdie instruksies het egter meer tot wrywing gelei. Dit veroorsaak dat die Xhosas weer eens oor die grens begin stroom en hulself in die Suurveld begin vestig. Daarop besluit Somerset om op 27 Januarie 1817 in die geselskap van sy twee dogters, die Koloniale Sekretaries, Kolonel Bird, Thomas Sheridan en dr James Barry die oosgrens te besoek. ${ }^{74}$ Op 30 Maart besoek hy Gaika en dink verkeerdelik dat hierdie opperhoof die septer swaai oor al die Xhosas. Gaika beloof plegtig dat die veediefstalle end sal kry, maar dat Ndlambe hom nie wil gehoorsaam nie. $^{75}$

Hierop word die spoorstelsel ingestel, waardeur gesteelde vee by die kraal waarheen die spore lei, opgeëis kon word. Daar word egter oor die hoof gesien dat die meeste diefstalle deur enkelinge gepleeg word en die opperhoofde dit selde weet. Die boere kompenseer dan deur meer vee terug te neem vir tyd en moeite opgeoffer. Die opperhoofde voel ook nie gebind 
deur ooreenkomste met die koloniale regering nie. $^{76}$

Op sy terugreis doen Somerset by al die militêre poste aan. Die meeste van hierdie poste (22) is na die 4de Xhosa-oorlog aangelê, dog eers gedurende die 5 de Xhosa-oorlog werklik gebruik. Daarom voel ek dat ' $n$ beskrywing van hulle hiér meer gepas is.

Die militère poste vanaf die mond van die Visrivier was in die volgende volgorde:

Agt myl van die see was die Laer Kafferdrifpos. ${ }^{77}$ Die meeste van hierdie poste is ' $n$ eenvoudige konstruksie van ' $n$ vierkantige ruimte, ingesluit deur ' $n$ taamlike hoë ringmuur van gekapte klip gemessel met klei of "daga". Teen die binnemuur was die barakke vir die soldate opgerig en die oorblywende oop gedeelte is as perdekraal gebruik. Op 'n klein afstand van die eerste muur was die tweede muur wat van skietgate voorsien was. $^{78}$

Vier myl verderaan kry ons Bo-Kafferdrifpos, wat ' $n$ baie belangrike deurgang na Xhosaland verskaf het. Hierdie pos is heelwat vergroot deur nog 'n muur buite-om te plaas. Op die hoeke van hierdie muur was daar bastions vir veldartillerie wat na die rivier heen wys. Buite-om hierdie pos was daar verskeie geïsoleerde geboue, waarvan een ' $n$ bakhuis was. ${ }^{79}$

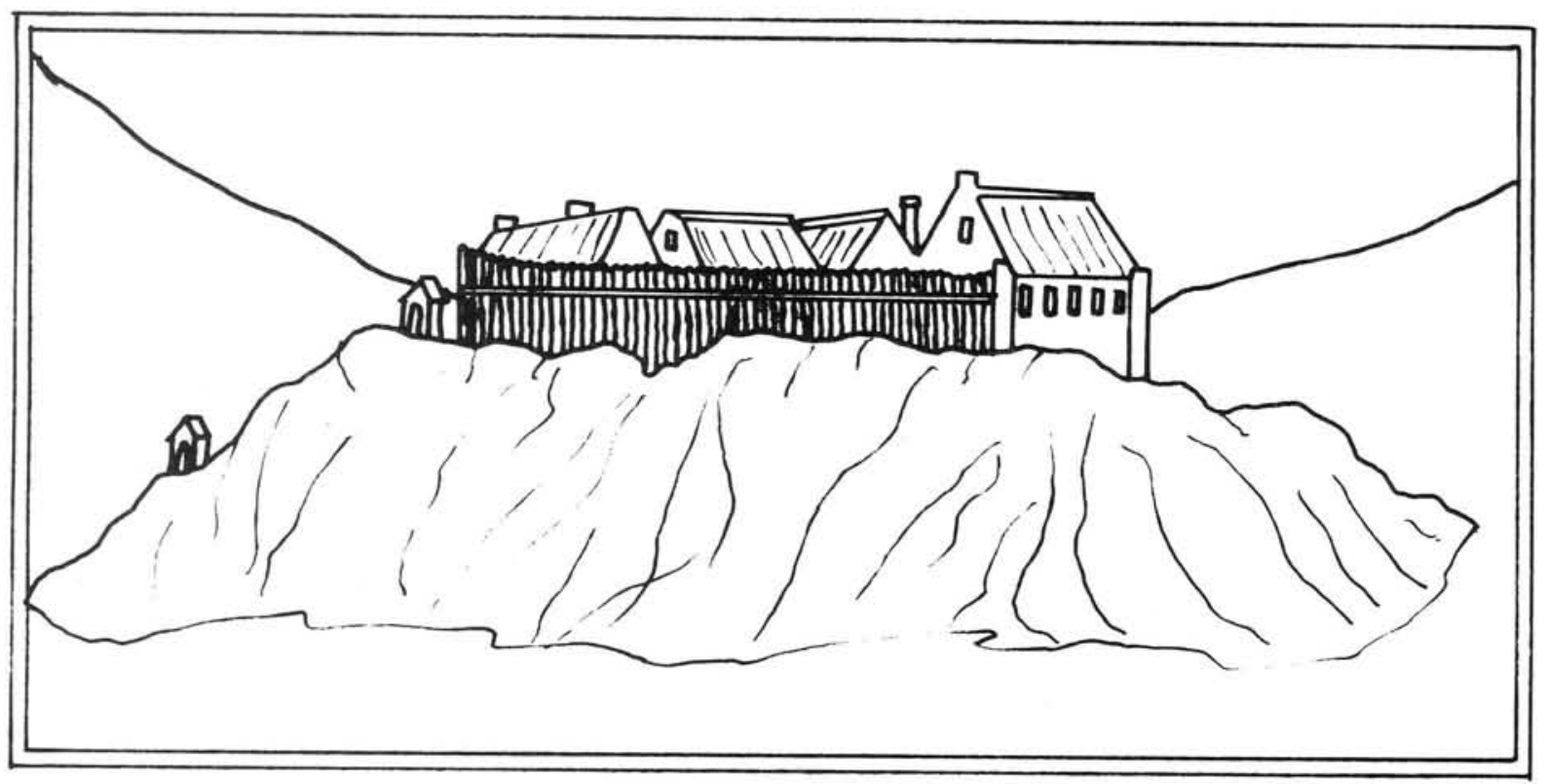

Bo - Kafferdrifpos

Vandaar was die omgewing bosagtig, ruig en onmoontlik om te verdedig. Een uur te perd verder, effens wes van Bo-Kafferdrifpos, was die Waaiplaatspos. Die volgende pos was meer by die rivier, naamlik Hermanuskraal (die latere Fort Brown). ${ }^{80}$ Dis vernoem na die rebelse Hottentot Hermanus Xogomesh, wat die rebelle in 1851 in die aanval op Fort Beaufort gelei het. Hy was 'n droster van Magomo se stam. Die fort self bestaan uit 'n groep geboue, omring deur 'n hoë klipmuur wat ruim huisvesting aan mansskappe en perde gebied het. In die een hoek was 'n kanontoring van sowat 3,5 meter in die vorm van ' $n$ vierkant. ' $n$ Kliptrap het vandaar ingang verleen na ' $n$ vertrek met skietgate. Onder die vloer was ' $n$ magasyn en bo-op die dak ' $n$ kanon wat in verskillende rigtings kon draai. In verband met die kanon skryf luitenant Montgomery Williams van die Royal Engineers in 1835 aan Sir Benjamin D'Urban, dat die drieponderkanon en sy toebehore by die fort gelaat is. ${ }^{81}$

In 1835 is dit deur D'Urban tot een van die grootste grensforte omskep en toe vernoem na luitenant Brown van die 75ste Regiment, wat bevel gevoer het daar tydens die 1835-oorlog. Eintlik was hy 'n taamlike onbelangrike figuur teenoor die persone waarna die ander forte vernoem is. Dié fort was belangrik omdat dit op die hoofpad (Queen's Road) tussen die Oosgrens en Grahamstad geleë was ${ }^{82}$ Die totale koste vir die bou van die fort beloop $£ 4000$ en is opgerig deur A.G. Bain. Teen 1861 is dit ontruim. ${ }^{83}$ 


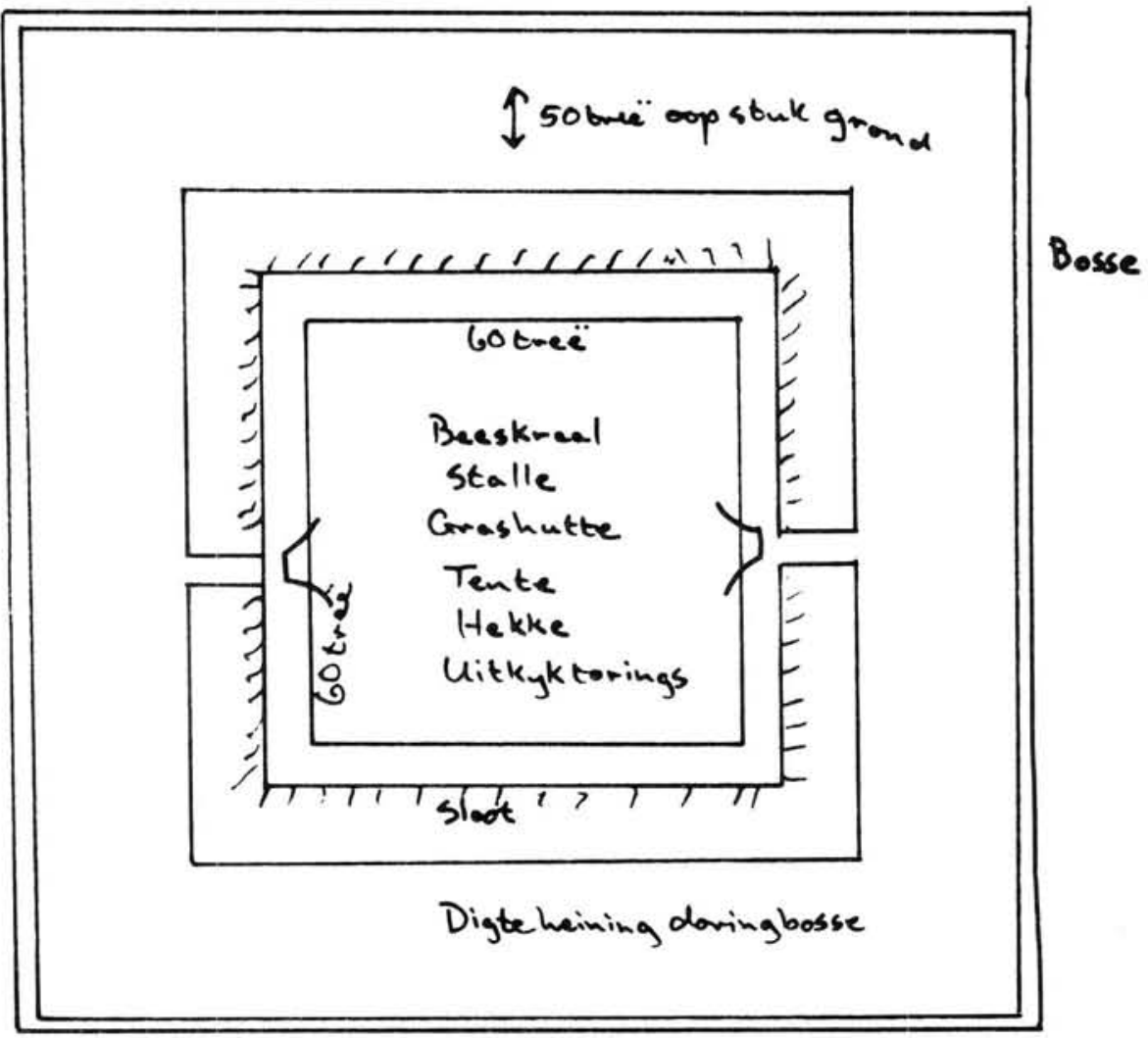

Algemene Plan van 'n Militêre Pos

Nadat Somerset Hermanuskraal verlaat het, doen sy geselskap $1 \frac{1}{2}$ uur verder te perd by Koetzersdrifpos aan - daarna De Bruinsdrifpos (1 $\frac{1}{2}$ uur verder), Wentzel Coetzee se pos op sy plaas ( $1 \frac{1}{2}$ uur verder aan) en Junction Drifpos ( $2 \frac{1}{2}$ uur verder geleë), by die sameloop van die Klein- en Groot-Visrivier. ${ }^{84}$ Die volgende drie plase, Van der Merwe ( $\frac{1}{2}$ uur verder), De Lange $\left(\frac{1}{2}\right.$ uur te perd verder) en Paul Bester ( $\frac{1}{2}$ uur verder aan), vorm die volgende militêre poste. Verderaan op sy reis, doen hy ook aan by Van Aardtpos (Longhope Siding) ( $\frac{1}{2}$ uur verderaan), Roode Waal (1 uur te perd verder) en die heel verste pos - Krugerspos ( $\frac{3}{4}$ uur verder) naby Slachtersnek, waar die Baviaansrivier invloei. ${ }^{85}$

Van Aardtpos was 'n soort hoofkwartier op die plaas Verkeerde Water, met ' $n$ kaptein in bevel. Daar naby was ook 'n militêre begraafplaas. ${ }^{86}$

' $n$ Tweede reeks forte, wat gedien het as verdedigingslinie, is dieper in die kolonie ingebou en was die volgende: Prinsloopos naby Cookhouse, Somerset Farmpos, by Grahamstad was Fort England en later ander ook, die Rietbergheuwelpos tussen Rietberg en Coerney, die Coerneypos, Sandflatspos, Rautenbachdrifpos op die
Boesmansrivier, Vermaakspos, Meyerspos, die Addodrifpos op die Sondagsrivier en op die mees westelike plaas van Jacobus Oosthuizen ook 'n pos. ${ }^{87}$

Die totale aantal soldate by al bogenoemde poste was 42 kapteins en 1062 troepe. Elke pos het bestaan uit soldate van die 21 ste Light Dragoons, gebruik vir kommunikasie en die Hottentot Corps, wat hoofsaaklik gebruik is vir opvolgoperasies. Patrollies moes twee keer daagliks uitgaan om spore te soek, naamlik in die oggend en middag. ${ }^{88}$

Op 22 April 1819, tydens die aanval op Grahamstad, kry die Oostelike Barakke (later bekend as die Fort England Barracks) sy eerste en enigste vuurdoop deurdat Ndlambe en Makanna tydens die Vyfde Xhosa-oorlog die uitwissing van Grahamstad en die Britse hoofkwartier van die Oostelike Provinsie beplan. Die militêre kamp was eers binne in die dorp, toe slegs sewe jaar oud, maar is later twee myl suidooswaarts verskuif. Stewige kasernes met klei en bakstene is hier opgerig. ${ }^{89}$

Op 21 April stuur Makanna 'n uittartende bood- 
skap aan kolonel Thomas Willshire, maar hy was ongelukkig op ' $n$ verkenningstog na die hoogland oos van Grahamstad in die rigting van Bothaskop. Kaptein Trappes is in bevel agtergelaat. Willshire sien egter duisende Xhosas op die hoogland en haas hom terug na Grahamstad. ${ }^{90}$

Intussen tref kaptein Trappes voorsorg. Sestig manskappe van die Royal African Corps moes die kaserne verdedig, terwyl die res plus 32 burgerlikes in 'n lang linie ontplooi is. ${ }^{91}$ Om presies eenuur begin die aanval deur 10000 Xhosas. Selfs die vierkant van die kaserne word binnegedring. Duisende Xhosas sneuwel, terwyl slegs drie Britte die lewe laat en vyf gewond is. Die gebeurtenis is van belang omdat ' $n$ handjievol manskappe Grahamstad red en sodoende dus ' $n$ aanval in die Kolonie afwend. ${ }^{92}$

Daarop besluit Somerset om die grense van 'n neutrale gebied tussen die Keiskamma- en Laer Tyumierivier na Elandsberg, die Winterberge en die sameloop van die Baviaans- en Visrivier vas te stel. ${ }^{93}$

Somerset was ongelukkig ook die eerste om die neutrale gebied te skend deur twee militêre poste by die Gargai- en Gwangariviere op te rig. ${ }^{94}$ Dit is gebou om die ooreenkoms met Gaika in verband met die neutrale gebied te handhaaf. Die Gargaipos was by Funah se kraal op 'n uitloper van die Keiskammarivier, ongeveer 'n kwartmyl van die samevloeiing, terwyl die Gwangapos by ' $n$ ander uitloper van die Keiskammarivier gebou is om sodoende beheer uit te oefen oor Cungwa en sy ondergeskikte kapteins. Majoor Halloway van die Royal Engineers het albei se planne opgetrek en hulle laat bou ${ }^{95}$

Nadat Somerset die plek uitgesoek het vir die bou van 'n fort op die wesbank van die Keiskammarivier, begin majoor W.C. Halloway met bouwerk aan die fort in November 1819. Die fort Fort Halloway, is egter nooit voltooi nie, want terwyl Somerset in Mei 1820 in Londen is, besluit die waarnemende goewerneur Donkin dat hierdie fort geen beskerming vir troepe verskaf nie dus staak hy bouery. ${ }^{96}$

Donkin soek toe ' $n$ ander stuk grond nader aan die rivier uit en beveel op 29 Mei 1820 vir luitenant Rutherford van die Royal Engineers om, soos eers genoem, die Keiskamma Barakke met stalle en 'n hospitaal vir 250 mansskappe te bou. ${ }^{97}$ Met Somerset se terugkeer in 1821 was hy baie ontevrede, dog Fort Willshire was reeds klaar gebou, gernoem na luitenant-kolonel
Thomas Willshire van die 38ste Regiment en bevelvoerder van die oosgrensmagte..$^{98}$

Op 23 Julie 1824 kondig Somerset 'n jaarlikse ruilhandel by Fort Willshire aan en lê die reëls daarvoor neer: ${ }^{99}$

Alles moet onder direkte toesig van die kommandant wees. Verkope sal slegs op Woensdae, Donderdae en Vrydae plaasvind. Ruilartikels moet ivoor, beesvelle, velle van wildediere, snuisterye, mielies en mandjies wees. Aan die Xhosas sal klere, komberse, leerbroeke, messe, tonteldose, landbougereedskap, tee, koffie, suiker, byle, potte, ketels, knope en krale geruil word. ${ }^{100}$

Die eerste verkope het op 18 Augustus 1824 plaas gevind. Op 17 November 1825 is daar 'n ordonnansie gepubliseer om beeste ook te ruil. ${ }^{101}$

In 1828 beskryf John Ayliff die ruilhandel by Fort Willshire as volg: Die Union Jack word gehys, terwyl 500 persone in twee rye 100 meter uit mekaar staan. Dan begin die kopery in alle erns. 'n Beul blaas elke keer as 'n ry klaar gekoop het. Aan die einde van die dag vind die stryking van die Union Jack plaas om sodoende die verkope af te sluit. ${ }^{102}$

Die ondersoek na die oorsake van Hintsa se dood is onder andere daar gehou. In 1836 nadat die fort ontruim is, het Macomo, Gaika se oudste seun, hom daar kom inruim. Fort Willshire het die regering die ekwivalent van $\mathrm{R} 90000$ gekos en is later deur hom vir twee beeste aan 'n handelaar verkoop. ${ }^{103}$

Trompettersdrifpos (vernoem na die Hottentot vrybuiter) was $27 \mathrm{~km}$ van die mond van die Visrivier, en is een van die oudste driwwe deur dié rivier. In 1817 het Somerset 'n militêre pos daar opgerig om toe te sien dat sy spoorstelsel uitgevoer word. ${ }^{104}$

In die daaropvolgende jare is militêre poste ook opgerig by Cawoodpos, Fraser's Camp, Double Drift en Bothasdrif. Elkeen van hierdie poste het bestaan uit ' $n$ hoë klipringmuur, wat barakke vir soldate en perde omsluit het. Vandaar is gereelde patrollies uitgestuur om die oosgrens te beveilig na die hewige Vyfde Xhosa-oorlog. ${ }^{105}$

Nog ' $n$ interessante bouwerk was die Martellotoring, wat sy naam verkry het van die Britse 


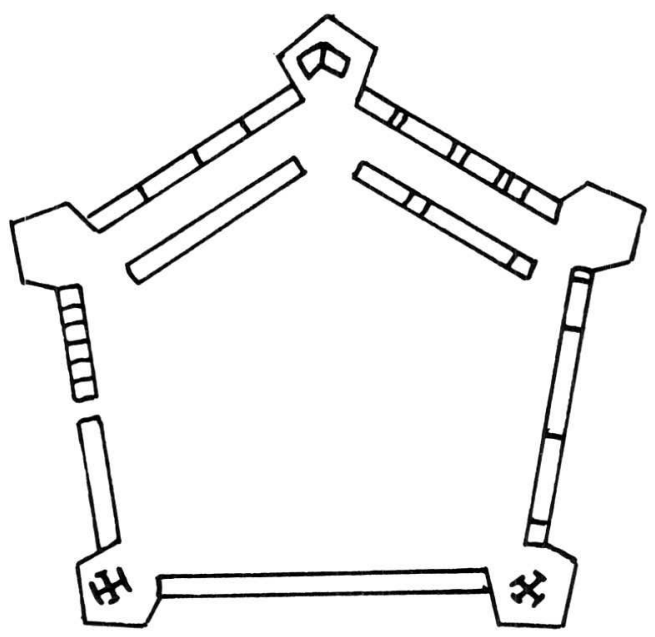

G.E.Cory: The Kise of South Asvica, I, p. 402 .

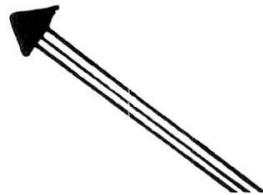

Fort Halloway

Fumaluse kracal-Crargai. late Font Willshire

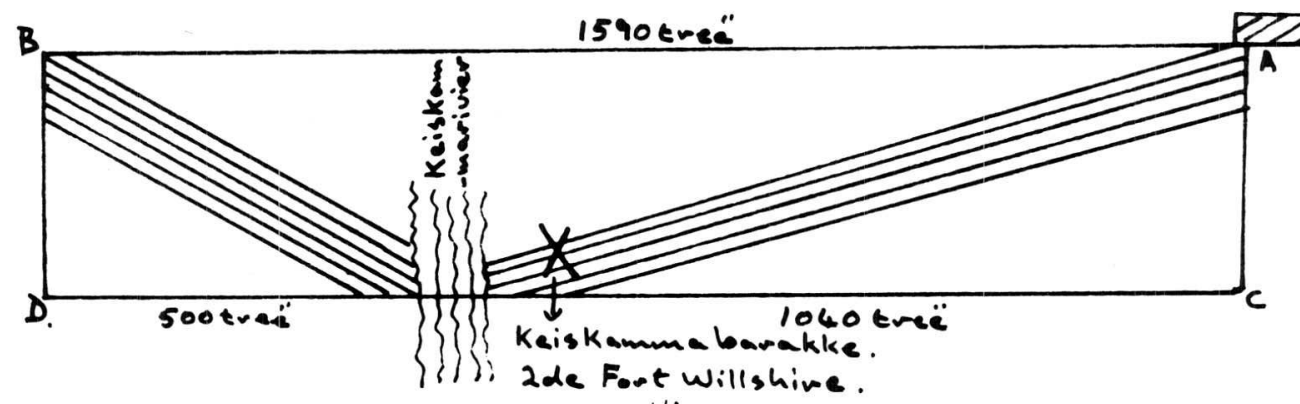

G.E. Cory: The Rise of South A frice, I., p. 400.

(uan Blue Book on South Astican' A'sbairs, 1819)
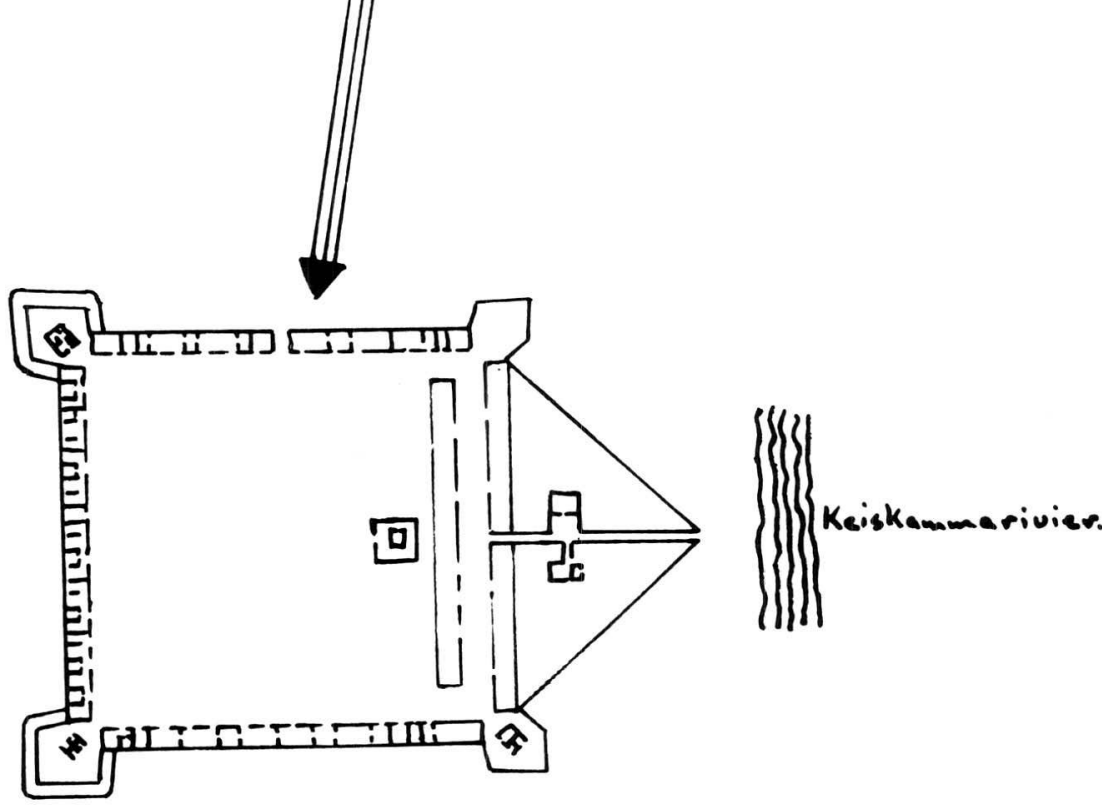

Fort Willshire 
vlootaanval op Kaap Martello in Korsica in 1794. Dit kon vir ' $n$ geruime tyd teen ' $n$ groot oormag weerstand bied. Die Martellotoring was geleë in die Fort Beaufort-distrik. Hierdie stewige ronde toring was gebou van groot bewerkte klippe en het bo-op ' $n$ houtstellasie gehad, waarop ' $n$ kanonnetjie wat in die rondte kon draai, geplaas

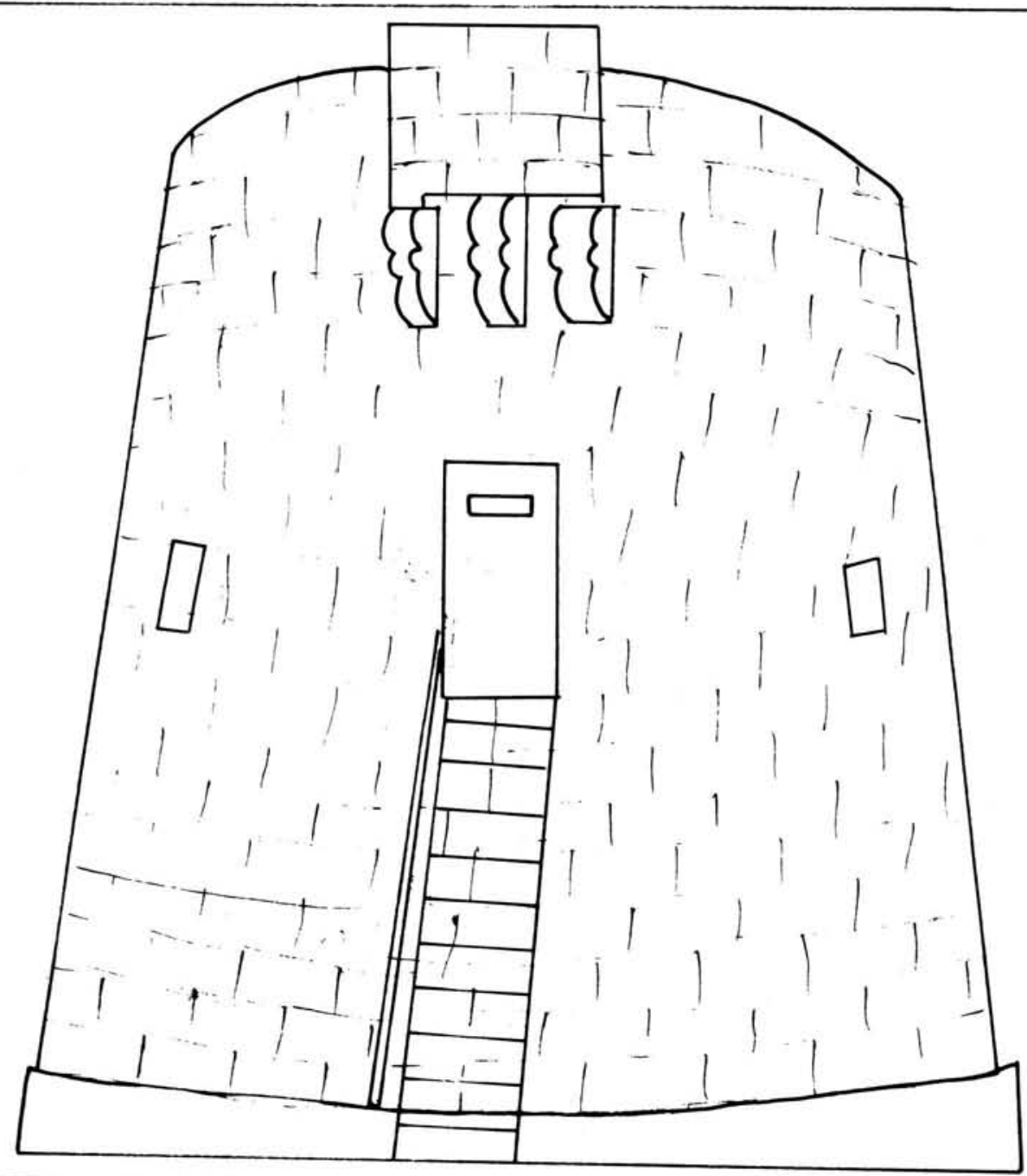

Die Martello-Toring 


\section{Hoofstuk V \\ Die sesde Xhosa-oorlog, 1834-1835}

Tussen 1824 en 1834 raak die stamme op die Oosgrens rusteloos as gevolg van die Lifiqanaoorloë van Umsilikazi. Hierdie onderlinge oorloë tussen die swartes het veroorsaak dat die ander swart nasies, van agter, die oosgrensstamme vasdruk teen die grensboere. Dit maak hulle rusteloos en plaas geweldig stremming op die militêre poste. ${ }^{107}$

Die bring mee dat Elandpos op 'n heuwel gebou word, om die Lushingtonpas deur die Tyumievallei te beskerm. Vroeër is baie elande daar aangetref, en sodoende kry die pos sy naam. ${ }^{108}$ Die datum van presiese oprigting is onbekend, dog die offisiersmenasie word in 1830 opgerig en die magasyn in 1832. Gesteelde vee is soms daar gelos om deur die wettige eienaars opgeeis te word. Dit is gebou deur die Royal Engineers en beman deur die Cape Mounted Rifles. ${ }^{109}$

Op 16 Januarie 1833 arriveer Sir Benjamin D'Urban as nuwe goewerneur aan die Kaap. Sy bewindstydperk word beskou as van die belangrikste in die SA geskiedenis. Een van sy opdragte was om ' $n$ definitiewe naturelle beleid daar te stel. ${ }^{110} \mathrm{Nog}$ 'n belangrike opdrag kom in November 1833 van die Koloniale Sekretaris, mnr Stanley, wat D'Urban beveel om die noodsaaklike kommandostelsel met iets anders te vervang. ${ }^{11}$

Agente moes tussen die hoofmanne geplaas word om hulle te beïnvloed deurdat hulle $£ 600$ aan salarisse sou ontvang. Deur middel van korrespondensie met dr Philip beskou hy verkeerdelik die noord- en oosgrens as dieselfde - dus geld die beleid orals. ${ }^{112}$

Ook weet Magoma van die onenigheid tussen die boere as gevolg van die vrystelling van slawe. Boonop verkoop sommige boere reeds lankal gewere en ammunisie aan die Xhosas. Baie Hottentot weglopers vul ook die Xhosas se getalle aan. Hulle is verwelkom, aangesien hulle vuurwapens besit het. Numeries was die Xhosas sterker as voorheen. Vorige oorloë het hulle waardevolle oefening gegee. Die Kolonie lê dus vet en onbeskermend - dus is die prooi makliker as voorheen. ${ }^{113}$

Teen Desember 1834 begin die Xhosas huise afbrand en mense uitmoor. ${ }^{114}$ Teen die eerste week van Januarie 1835 was die Xhosas in beheer van die hele oosgrens. Klein afdelings sol- date by Bo-Kafferdrifpos, Committeesdrifpos, Hermanuskraal (Fort Brown) en ander poste langs die Visrivier kon skaars hul posisies behou teen die hordes wat die Kolonie by dié plekke binnekom. Die totale militêre mag op daardie tydstip was 775 soldate. 7000 mense vlug na Grahamstad om skuiling te vind. Kolonel Somerset se militêre vermoë was swak. 'n Mens kry die indruk dat, met die aankoms van die Xhosas by ' $n$ militêre pos, dit die teken was om dit te ontruim. Dit was die geval met Fort Willshire, die Gualana- en Kafferdrifposte - almal is so vinnig ontruim behalwe Fort Beaufort. Dié Katrivierpos is behou as militêre pos en ook nie aangeval nie, omdat die Xhosas gedink het dat die Hottentotte hulle sou help. ${ }^{115}$

Op hierdie tydstip word Kolonel H.G. Smith aangestel as bevelvoerder van die hele grens en lê die afstand van 600 myl van Kaapstad na Grahamstad in ses dae af. Hy verdeel die leër in drie afdelings. Teen Februarie 1835 is die Xhosas oor die Visrivier teruggedryf. Die einde Maart begin troepe en burgers met ' $n$ opvolgoperasie in Xhosaland en Hintsa gee op 30 April oor. Op 10 Mei word die Keirivier die nuwe grens: Hintsa betaal skadevergoeding. ${ }^{116}$

Slegs vriendskaplike stamme mag nog in die gebied bly. Die Keirivier was egter nie ' $n$ goeie grens nie, omdat dit steeds verder van die koloniale regering was; dus moeiliker om te kontroleer en te verdedig. Die oosgrens was nou nog dunner bevolk as vroeër en van militêre sekuriteit was daar min sprake. ${ }^{117}$

Op 10 Mei 1835 word die gebied tussen die Keiskamma- en Keirivier formeel tot die Provinsie van Koningin Adelaide verklaar. Kolonel Smith word in bevel van die militêre hoofkwartier by King Williamstown geplaas. Belangrike forte word nou in die gebied gebou om die grens beter te beveilig. ${ }^{118}$

\section{Hoofstuk VI \\ Die gevolge van die Sesde Xhosa-oorlog}

Die Sesde Grens-oorlog, by verre die strafste, het geweldige geestelike en materiële eise gestel. Dus is besluit dat die enigste oplossing was om weer eens ' $n$ reeks forte ter beskerming van veral die mense van die nuwe Provinsie van Koningin Adelaide, op te rig. Tydens Sir Benjamen D'Urban se besoek aan die oosgrens is daar dan ook tot hierdie stap oorgegaan. 
Ter beveiliging van die ganse gebied, is begin met die bou aan 'n uitgebreide netwerk van forte vanaf die Visrivier tot by die Keirivier. Die Visrivier het nog altyd as eerste linie gegeld. Aan hierdie linie is nou gebou die Trompettersdriffort, Double Drift-fort, Fort Brown (vroeër Hermanuskraal), Fort Beaufort, Fort Armstrong en Post Retief. ${ }^{119}$

Die tweede linie het vanaf Peddie noordooswaarts langs die Keiskamma- en Tyumierivier gestrek en is gevorm deur Fort Peddie, Fort Montgomery Williams, Line's Drift, Fort Willshire en Fort Thompson.

In die nuwe Provinsie van Koningin Adelaide is ook ' $n$ aantal forte gebou, onder andere aan die bo-loop van die Keiskammarivier: Fort Cox en Fort White; aan die Buffelsrivier: Fort Murray, Fort
Hill (Kingwilliamstown), Fort Hardinge en Fort Beresford; aan Gonubierivier: Fort Waterloo en ver na die ooste aan die Keirivier: Fort Warden. ${ }^{120}$

In 1822 het luitenant-kolonel H. Maurice Scott 'n militêre pos by die Katrivier gebou om ' $n$ oog oor die Xhosa strooptogte te hou. Dit word vernoem na Lord Charles Somerset se vader, Duke of Beaufort. Die dorp Fort Beaufort is toe in 1837 uitgelê, terwyl permanente uitbreidings in die tyd aan die fort aangebring is. ${ }^{121}$

Fort Armstrong, naby Balfour was oorspronklik Camp Adelaide en, deur middel van D'Urban se grensreëlings, word dit in ' $n$ fort omskep, vernoem na kaptein A.B. Armstrong. Hy het gesorg dat die Hottentotte lojaal bly tydens die Sesde Xhosa-oorlog. ${ }^{122}$ Dit word in 1836 op 'n heuwel

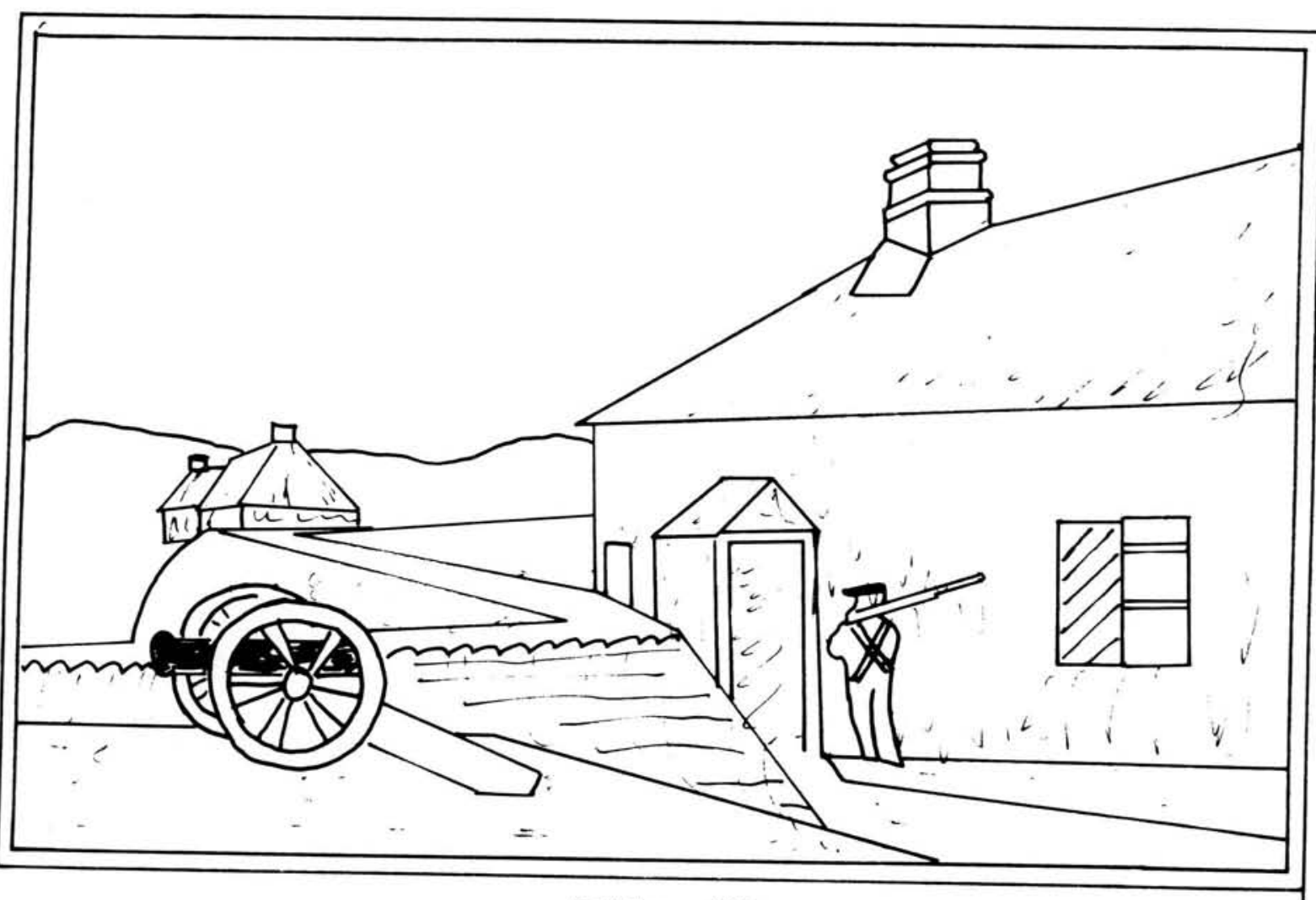

Fort Brown 1838 


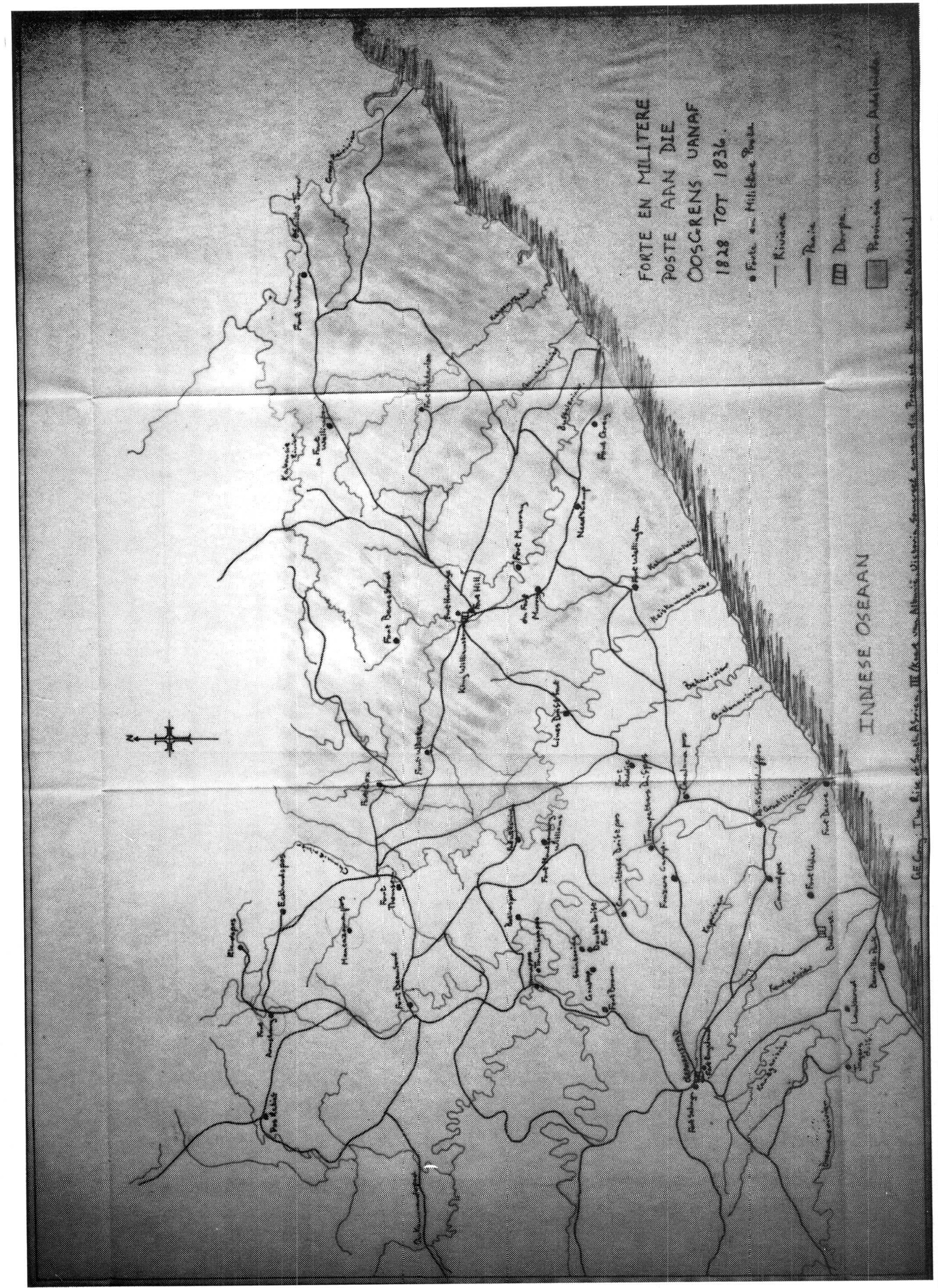




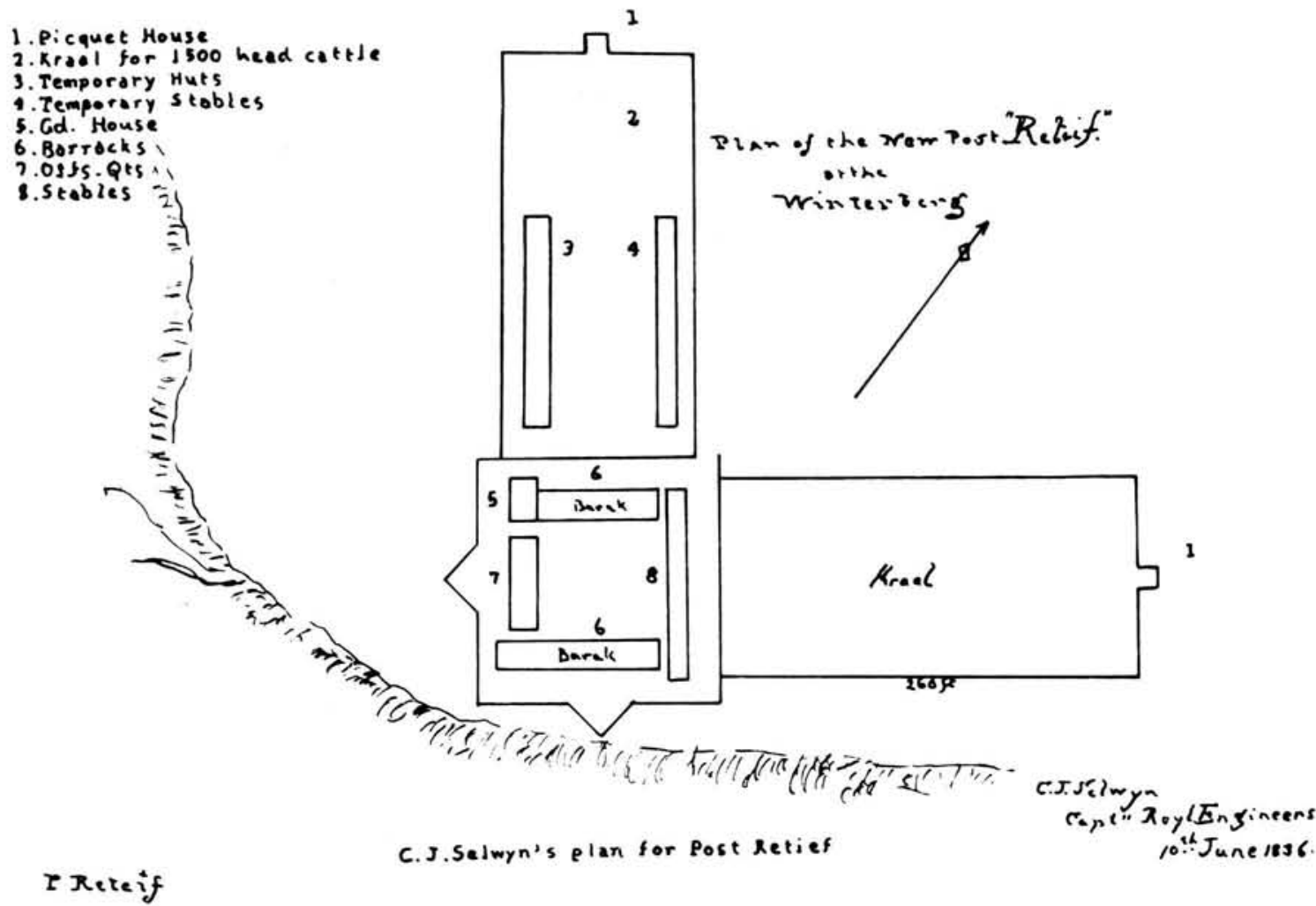

M. Mc Dowall: Post Reties (Grahamstown Histarical Society, 1971, p.35.

\section{Post Retief}

opgerig en is aan drie kante deur die Katrivier omring. ${ }^{123}$ Die fort self is deur klipmure omring met die nodige militêr geboue in die binnekant, asook klein huisies vir die Hottentotsoldate en hul families buitekant die mure. Die fort moes beskerming aan die Katriviernedersetting verleen. ${ }^{124}$

Post Retief, geleë in die Winterberge noord van Grahamstad, was eerder 'n militêre polisiekamp as ' $n$ militêre pos. Dit het beskerming gebied aan die boere van die Winterberge. ${ }^{125}$ Dit was ongeveer vier myl van die voet van die Didimaberg geleë en is vernoem deur D'Urban in 1836 na die Voortrekker, Pieter Retief. Binne de hoë mure het ons 'n hospitaal, stalle, store, barakke en magasyne aangetref. ${ }^{126}$

Fort Peddie is gedurende die oorlog gebou ter beskerming van die 16000 Fingo's, wat in 1835 met hul 22000 beeste deur D'Urban van Gcale- kaland na Peddie verskuif is. ${ }^{127}$ Die fort is onder toesig van kolonel John Peddie van die 27 ste Regiment (Seaforth Highlanders) in die vorm van 'n ster gebou. Die mure was agt voet hoog en wyd genoeg om ' $n$ hele paar sesponders te dra. Rondom die fort was ' $n$ sloot en binne-in was die gebou van die kommisariaat geleë, sowel as die pakkamers, 'n magasyn en 'n wagkamer. ${ }^{128}$

Fort Montgomery Williams, 'n klein stervormige fort is in Julie 1835 deur luitenant Montgomery Williams van die Royal Engineers gebou en wel met die doel om deur middel van patrollies langs die Visrivier dié gebied te beveilig. ${ }^{129}$ As gevolg van 'n gebrek aan water verloor hy sy belangrikheid en word in 1836 ontruim. ${ }^{130}$

Die plek waar Line Drift Fort opgerig moes word, is deur D'Urban self uitgesoek naamlik op die wesbank van die Keiskammarivier, naby Eno se kraal en ongeveer 'n driekwartmyl van die drif 
aan die koloniale kant van die rivier. ${ }^{131}$ Dit was vierkantig met hoë mure om sowel die Fingo immigrante as die drif te beskerm. ${ }^{132}$

Fort Thomson, vernoem na luitenant-kolonel R.T. Thomson, bevelvoerende offisier van die Royal Engineers, is ook in opdrag van D'Urban opgerig. ${ }^{133}$ 'n Garnisoen van 10 kavallerie, 30 infanterie van die 72ste en 75ste Regiment (Seaforth Highlanders en Gordon Highlanders) en 30 soldate van die Cape Corps (Imperial Cape Mounted Riflemen) is daar gevestig om ' $n$ oog oor die 1600 Fingoes te hou. Thomson het dit ontwerp en gebou. ${ }^{134}$

As gevolg van sy strategiese ligging en gevaarlike omgewing, word Fort Cox as een van die belangrikste forte beskou. Dit was omring deur hoë berge en digte bosse en is gebou op die hoogste deel van die land, en soos ' $n$ skiereiland omring deur die Keiskammarivier en Amatolaberge. ${ }^{135}$ Die fort is vernoem na majoor William Cox van die 75ste Regiment en bevelvoerder van die eerste en vierde divisies van sir D'Urban se leër in $1835 .{ }^{136}$

Dit het bestaan uit vier hoë klipmure, met ' $n$ vierkant van 60 meter in deursnit, met ' $n$ ingang in elke muur. Binne-in was 'n stewige kruithuis, slaapplek vir offisiere, stalle en 'n kookhuis of kombuis. Die soldate het in tente gebly. Buite die fort, regoor die ingang, was driehoekige waghuisies met die basis na die opening in die muur daarsonder sou die Xhosas ongesiens vanaf die rivier se walle tot die fort se muur kon kruip. ${ }^{137}$

Fort White was heelwat kleiner as Fort Cox en was die verbinding tussen laasgenoemde fort en King Williamstown. Oorspronklik het D'Urban die Umdezini (Groenrivier) uitgesoek om die fort op te rig, dog kolonel Smith stel op 27 Augustus 1835 vir luitenant Montgomery Williams van die Royal Engineers an, om ' $n$ meer geskikte plek uit te soek. ${ }^{138}$ Die fort is vernoem na majoor T.C. White, wat saam met die burgerkommando's gedien het en op 13 Mei 1835 by die Basheerrivier die lewe gelaat het. ${ }^{139}$ Dis gebou aan die voet van die Tabinda berg, ' $n$ bekende landmerk in die Amatolaberge en het bestaan uit vier hoë mure om ' $n$ vierkant te vorm. ${ }^{140}$

Fort Murray, vernoem na kolonel Murray van die 42ste Regiment (Black Watch) was 'n replika van Fort Beresford en gebou naby Mount Coke op die walle van ' $n$ tak van die Buffelsrivier in $1835 .{ }^{141}$ In 1836 word dit ontruim met die Britse regering se anneksasie van die Provinsie van Koningin Adelaide.

Fort Warden, vernoem na Kaptein Henry Douglas Warden van die Imperial Cape Mounted Riflemen, wat later die Resident van die Oranjeriviersoewereiniteit sou word, is by Impatshana op die wesbank van die Groot Keirivier in die distrik Komga gebou. ${ }^{142}$

Tydens sy besoek, het goewerneur D'Urban vyf myl van dié rivier kamp opgeslaan en die manne het dadelik begin met die bou daarvan. Dit kon egter nie 'n baie stewige struktuur gewees het nie, want dis in net tien dae voltooi. ${ }^{143}$ Die fort was omring deur ' $n$ sloot vyf voet breed en drie voet diep. Voorsiening is ook gemaak vir die beskerming van beeste. Op ' $\mathrm{n}$ afstand is dit omring deur ' $n$ ondeurdringbare heining van doringbosse en 'n oop deel van 50 treë, sodat niemand ongesiens kon naderkom nie. ${ }^{144}$

Fort Selwyn op Gunfire Hill (Grahamstad) is vernoem na kaptein (later majoor) C.J. Selwyn van die Royal Engineers. ${ }^{145}$ Toe Andries Stockenstrom, die nuwe luitenant-goewerneur van die oostelike distrikte, in Augustus 1836 in Grahamstad aankom, is 17 kanonskote vanuit dié fort ter ere van hom afgevuur. ${ }^{146}$

Volgens mnr T.H. Bowker, wat gehelp het met die bou van Fort Wellington, bestaan dit uit 'n sirkelvormige grondwal, ses voet breed, met 'n sloot aan die buitekant. In die middel was ' $n$ wagpos hoog bo-op vier groot boomstompe. Binne die oostelike walle was ' $n$ kruitmagasyn, stoorkamer en vier tente. Aan die buitekant was ' $n$ beeskraal en hutte gebou deur die Fingoes, 'n Paar manne onder luitenant Leslie was daar gestasioneer. Hulle het baie las gehad van veediewe omdat hulle gering in getal was. Die fort is deur kolonel Harry Smith na die held van Waterloo vernoem. ${ }^{147}$ Water en hout was skaars en gevaarlik ver van die fort. Gedurende die winter is daar baie beeste en perde dood as gevolg van die koue. ${ }^{148}$

Fort Usher was twee myl van die oosbank van die Kowierivier in die distrik Bathurst geleë en daarna is ook verwys as Usher's Mill of Usher's Camp. ${ }^{149}$ By Committees Drift oor die Visrivier en noordoos van Trompetters Drift, is ook ' $n$ pos aangelê. Daar was 70 tot 80 infanterie en 30 berede soldate gestasioneer. ${ }^{150}$

Confinement, soos die naam aandui, was detensie barakke. Dit is beman deur vyftien soldate. ${ }^{151}$ 


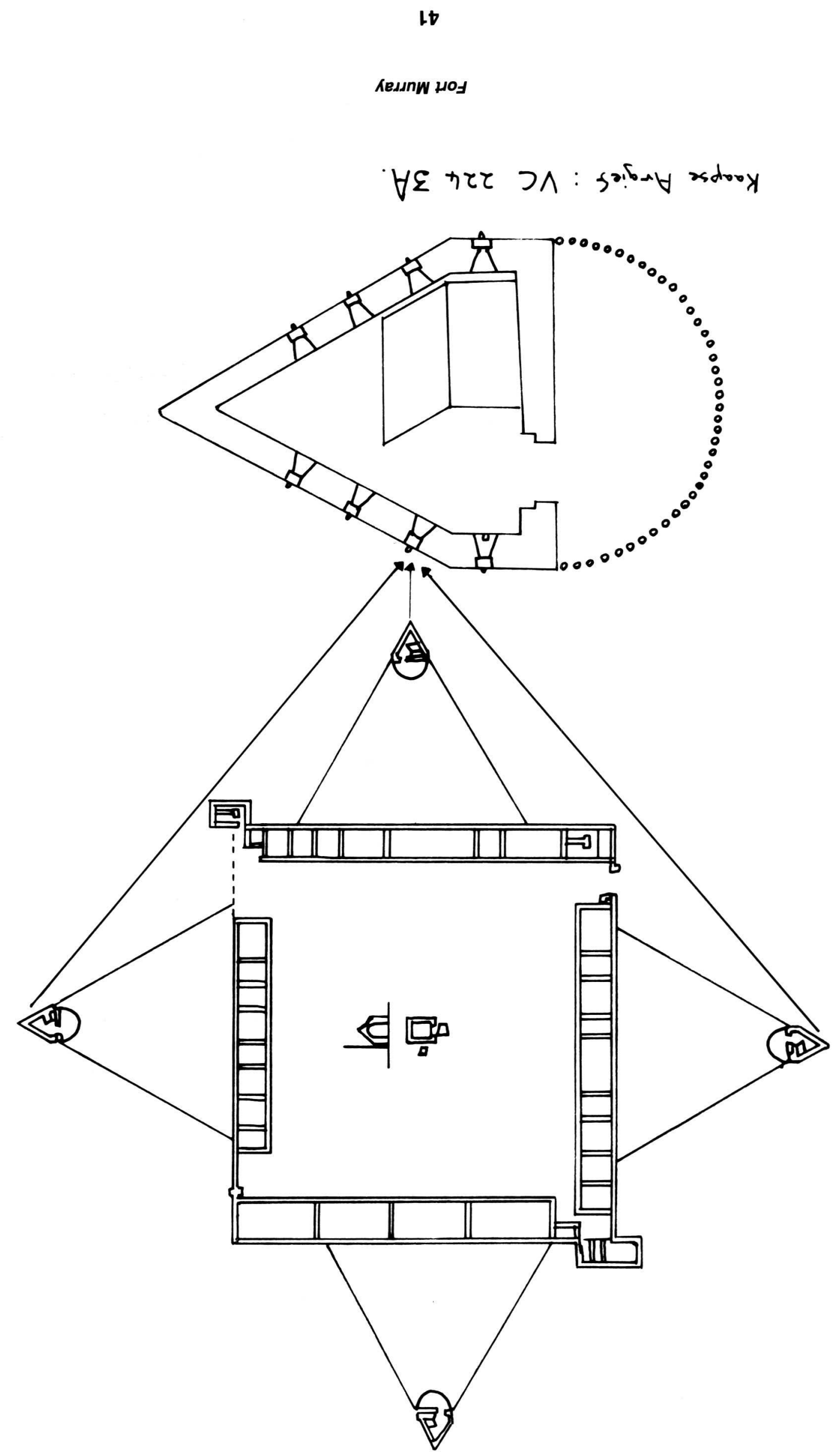




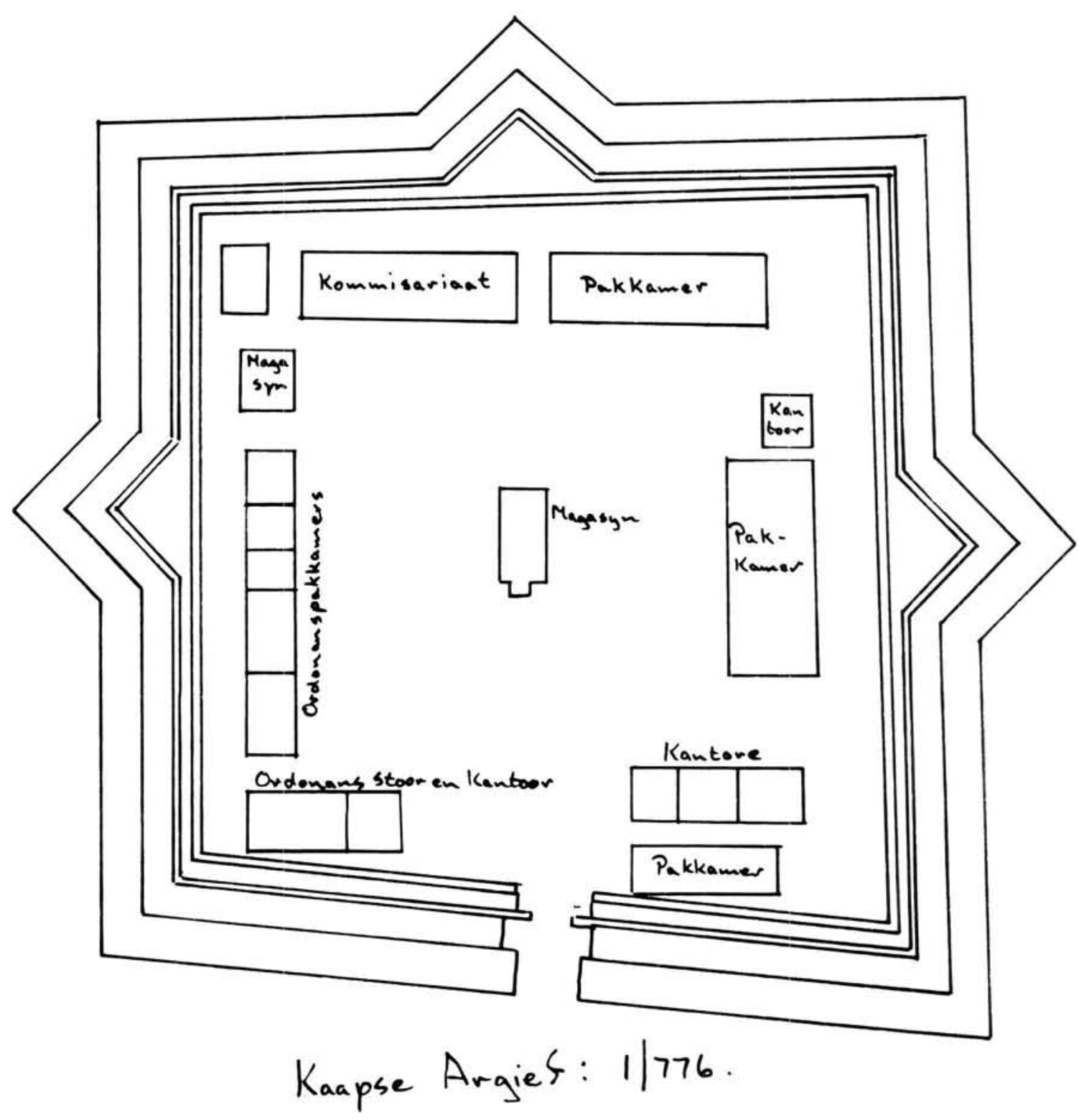

Grondplan van Fort Hill

Wagtorings of seintorings het ook onder andere ' $n$ baie belangrike aspek van die verdediging van die oosgrens uitgemaak. By die wagtorings (geen fortifikasies), is gewoonlik 'n hoop sout aan die brand gesteek om te waarsku teen dreigende gevaar. ${ }^{152}$

Die wagtorings het gestrek vanaf Frazers Camp ooswaarts en vanaf Governorskop weswaarts. Dis so gebou, dat daar ' $n$ half dosyn soldate en 'n sersant gehuisves kon word. Die verbinding het gestrek vanaf Fort Beaufort tot Dan's Hoogte, na Bothaspos, na Graskop tot by Governorskop en Grahamstad. Ook vanaf Trompetters Drift tot Piet Appelstoring, na Frazer's Camp, tot Governorskop na Grahamstad. ${ }^{153}$
Vir die eerste keer kon die grensboere aan die oosgrens veilig voel teen invalle uit Xhosaland, omdat daardeur nou daadwerklik en doelbewus gepoog is om hulle belange te beskerm en veeverliese te voorkom deur middel van die oprigting van forte en fortifikasies.

\section{Hoofstuk VII Slot en gevolgtrekking}

In die tydperk waaroor die tema handel, was daar ten spyte van strenge grensmaatreëls, drie ernstige grensoorloë. Na elke oorlog is planne beraam om die grens beter te beveilig. Hierdie planne kon nie altyd ten beste uitgevoer word nie, as gevolg van toestande buite die Kaapse 
regering se beheer, soos byvoorbeeld die volgende:

Tydens die Napoleoniese oorloë tot 1815 moes Brittanje alle beskikbare soldate aan die front in Europa gebruik. In dié tyd is die garnisoene aan die Kaap kwaai verminder.

Die resessie in Europa na die oorlog het veroorsaak dat Brittanje nie in staat was om die relatief onbelangrike oosgrens te finansier nie. Daar is dus hoofsaaklik van plaaslike soldate (21ste Light Dragoons en die Cape Corps) wat uit swak opgeleide Hottentotte bestaan het, gebruik gemaak. ${ }^{154}$ Boonop was hulle swak gedissiplineerd, bang en laks. Die Royal African Corps het weer hoofsaaklik uit kriminele bestaan en na hulle aankoms het die dissipline nog verder gedisintegreer op die oosgrens. ${ }^{155-156}$

'n Aspek wat volgens my mening een van die belangrikste was, is dat die oosgrens in die tydperk 1806 tot 1836 baie min werklike uitstaande militêre leiers gehad het. ${ }^{157}$ Uitsonderings was kolonel Graham ${ }^{158}$ en kolonel H. Smith. ${ }^{159}$ Die oorgrote meerderheid van die Britse soldate en hul bevelvoerders het in 'n vreemde land geveg as beroepsoldate. Die motivering wat 'n mens gewoonlik kry van soldate wat hul eie land verdedig, het dus grootliks ontbreek.

Dan was daar ook die oeroue menslike aspek. As daar vir 'n lang tyd niks op die front gebeur nie, raak die soldate gerus en juis in so 'n onbewaakte oomblik, slaan die vyand toe met slegte gevolge.

Patrollering het ook veel te wense oorgelaat. Kolonel Graham se opdragte aan bevelvoerders van poste was op papier uiters effektief in die teorie, dog dit is selde in die praktyk toegepas. ${ }^{160}$ Volgens my mening is daar ook heeltemal verkeerd patrollies geloop, wat natuurlik ook in 'n mate toegeskryf kan word aan die geweldige tekort aan soldate. Om net tussen die militêre poste op die Visrivier te patrolleer en boonop op gereelde en vasgestelde tye (twee patrollies per dag - in die oggend en middag), gee aan die Xhosas 'n pragmatige skedule van wanneer en waar om die gesteelde vee oor die grens te jaag. ${ }^{161}$

Moontlik kon die gebied rondom die militêre pos of fort opgedeel word in blokke. Die patrollies moes dan net voor eerstelig uitbeweeg om Xhosa-spioene te ontduik, die spesifieke blok deeglik patrolleer en net na laaste lig terugbe- weeg na die kamp. Verkenningspatrollies kon soms snags ook uitbeweeg om Xhosa-vure waar te neem, sodat met eerstelig 'n aanval geloods kon word.

Twee ander aspekte kon moontlik met meer welslae gebruik word. Eerstens kon die plaaslike bevolking (gekleurd) wat in die omgewing van die militêre pos gebly het, vergoed word vir inligting wat kon lei tot die inhegtenisname van die vee-diewe. ${ }^{162}$ Hulle ken die omgewing goed en weet waar geheime driwwe deur die riviere is, asook die veepaadjies. Buitendien is hulle beter versprei oor die grensgebied as die soldate. Dit kom my voor asof slegs die soldate en 'n paar burgerkommando's vir die hele grens verantwoordelik was.

Tweedens kon met behulp van 'n beter inligtingsnetwerk in Xhosaland ook groter welslae behaal word. Deur hierdie informante ruim te vergoed vir inligting, kon daar vinnig opgetree word deur effektiewe hinderlae te lê. Swart informante kon infiltreer of vanuit die kraal self gewerf word.

Na die 1834-1835 Xhosa-oorlog is in 'n mate só 'n sisteem in werking gestel deurdat residentregeringsagente by verskillende stamme geplaas is, om te adviseer en die hoofman te lei om sy mense te regeer, verkope van ammunisie en drank te verhoed, en kriminele sake te ondersoek. By die Gaikas is kaptein Stretch in Fort Cox geplaas, mnr Fleetwood Rawstorne by Ndlambe in Fort Waterloo gestasioneer, en by Fort Murray is mnr R. Southey geplaas om 'n oog oor die volgelinge van Tzatzoe, Umkye en Siwani te hou, en mnr J.M. Bowker in Fort Peddie om na die Gunukwebis om te sien. ${ }^{163}$

Die meeste militêre forte en poste was gebou om 'n aanval in oorlogstye af te weer en met uitsondering van 'n paar, was almal in staat om 'n redelike lang beleg die hoof te bied. Fort Wellington en Fort Montgomery Williams sou watertefore ondervind. ${ }^{164}$

Met die beplanning en bou van die forte en poste kom alle eer die Royal Engineers toe. Drie van hulle bevelvoerders met die forte wat hulle onderskeidelik gebou het, tussen hakies, was: kaptein (later majoor) C.J. Selwyn (Fort Selwyn ${ }^{165}$ en Post Retief $\left.{ }^{166}\right)$; luitenant Montgomery Williams (Fort White $^{167}$, Fort Montgomery Williams ${ }^{168}$ en heelwat militêre poste) en luitenant Rutherford (Fort Willshire ${ }^{169}$ ). Van hulle het ook leiding gegee met die bou van versterkte plaashuise. 
Die torte en poste is selde aangeval, behalwe Trompettersdrif, wat op 6 Maart 1835 aangeval is, terwyl die soldate besig was om 'n pont te bou. ${ }^{170}$ Makanna het ook op 'n keer Fort England aangeval. ${ }^{171}$

Wat die verdedigingswerke aan die oosgrens betref, sou ek sê dat dit dig en strategies oor die hele grensgebied versprei was. Die forte het dus 'n baie belangrike rol vervul en daarsonder sou die toestand heelwat hagliker gewees het. Dit het ' $n$ mate van sekuriteit aan die boere verskaf deurdat dit as 'n skuiling kon dien teen groot Xhosa-invalle. Die forte het aan hulle die nodige gevoel van veiligheid gegee, sodat hulle ongehinderd kon boer. Dit het ook daarenteen as 'n redelike goeie afskrikmiddel vir die Xhosas gedien en hulle het dit so ver moontlik probeer vermy.

*Mnr. P.J. Bezuidenhoud, BA is Departementshoof Ongwediva Opleidingsentrum Oshakati

\section{Bronnelys}

BURTON, Alfred W.: The Highlands of Kafferaria. Cape Town, 1969.

CANNON, Richard: Historical Records of the British Army (Cape Mounted Riflemen). London.

CORY, G.E.: The Rise of South Africa I en III. London, 1910 en 1919.

DRACOPOLI, J.L.: Sir Andries Stockenstrom, 1792-1864. The Origins of the Racial Conflict in South Africa. Cape Town, 1969.

ENGELS, L.J.: Sir Benjamin D'Urban's Handling of the Frontier Problems, 1834-1836. Ongepubliseerde M.A.-verhandeling. U.C.T. 1936).

GODLONTON, R.: A Narrative of the Irruption of the Kaffir Hordes into the Eastern Province of the Cape of Good Hope, 1834-1835. Cape Town, 1965

HAINE, Doreen P.: The Territorial Expansion of the Cape Colony Eastwards, between 1808-1836. (Ongepubliseerde MA-verhandeling, UCT, 1935).

HOCKLY, H.E.: The Story of the British Settlers of 1820 in South Africa. Kaapstad, 1948

LEWIS, It-kol: Reports upon the Eastern Frontier of the Cape of Good Hope, 1837.

METROWICH, F.C.: The Valiant but Once. Kaapstad.

METROWICH, F.C.: Frontier Flames. Books of Africa, 1968.

OBERHOLSTER, J.J.: Die Historiese Monumente van Suid-Afrika. Kaapstad, 1972.

POTGIETER, D.J.: Standard Encyclopaedia of Southern Africa IV en V. Kaapstad, 1971.

SMITHERS, A.J.: The Kaffir Wars, 1779-1877. London.

THEAL, George McCall: History of South Africa. London, 1893.

THEAL, George McCall: History of South Africa (1795-1834). London, 1891.

The Encyclopaedia Britannica X. Cambridge, 1910.

ZIETSMAN, P.L.: Die Verdediging van, en Verdedigingsbeleid op die Oosgrens gedurende die Tweede Engelse Tydperk tot aan die end van Si John Cradock se regering, insonderheid die bydrae van die Burgers. (Ongepubliseerde MA-verhandeling, UNISA, 1941).

Tydskrifte (S.A. Museum)

AFRICANA NOTES AND NEWS, Maart 1956, XII, no. I: KIRBY, Percival R.: Fort Brown (Hermanuskraal).

GRAHAMSTOWN HISTORICAL SOCIETY:

BENYON, John: Fort Willshire (Annals 1971, I, no. 1).

DONALD, J.M.: Fort Peddie (Annals 1971, I, no. 1)

MCDOWALL, M.: Post Retief (Annals 1971, I, no. 1).

STIRK, Doris: Lombard's Post (Annals 1971, I, no. 1).

THERON, M.L.: Eland's Post, Kaffir Drift Post, Fort England (Annals 1973, I, ก0. 3).

LOOKING BACK:
COETZEE, C.G.: Some Aspects of the Military History of Fort Hare and Fort Thomson (September, 1972)

HOFMEYR, C.: Fort Murray (Maart, 1972).

LORIMER, E.K.: Addo Drift and its Inns (Junie, 1964).

LORIMER, E.K.: Fortified Farms and other Settler Homes (Maart, 1963).

LORIMER, E.K.: Forts (September, 1962).

RANDLES, B.M.: Fort Willshire (Maart, 1972)

SCOTT, J.B.: Forts and Posts in the Eastern Cape (September, 1971).

THERON, M.L.: Cradock's Place (Maart, 1967).

THERON, M.L.: Fort Armstrong (Desember, 1973).

WALSH, B.B.: Line Drift Post (Maart, 1972).

THE JOURNAL OF THE HISTORICAL FIREARMS SOCIETY OF SOUTH AFRICA, Desember 1973, VI, no. 4

KLOTZ, W.: Fort Warden.

\section{Voetnotas:}

1. The Encyclopaedia Britannica X, 0679

2. The Encyclopaedia Britannica X, p 679

3. The Encyclopaedia Britannica $X$, p 679

4. The Encyclopaedia Britannica X, p 679

5. The Encyclopaedia Britannica X, p 679

6. The Encyclopaedia Britannica $X$, p 679

7. The Encyclopaedia Britannica X, p 680

8. The Encyclopaedia Britannica $X$, p 680

9. The Encyclopaedia Britannica $X$, p 680

10. The Encyclopaedia Britannica X, p 680

11. The Encyclopaedia Britannica $X$, p 680

12. The Encyclopaedia Britannica $X$, p 680

13. The Encyclopaedia Britannica X, p 680

14. The Encyclopaedia Britannica X, p 698

15. Sien laaste hoofstuk: "Slot en Gevolgtrekking", p ?

16. HAINE, D.P.: The Territorial Expansion of the Cape Colony between $1808-1836, \mathrm{p} 1$.

17. ENGELS, L.J.: Sir Benjamin D'Urban's Handling of the Frontier Problems 1834-1836, p 2.

18. ENGELS, L.J.: ... D'Urban's Handling of the Frontier Problems .... p 3.

19. ENGELS, L.J.: ... D'Urban's Handling of the Frontier Problems .... p 4

20. ENGELS, L.J..... D'Urban's Handling of the Frontier Problems ...., p 5.

21. HAINE, D.P.: The Territorial Expansion of the Cape Colony .... p 2.

22. HAINE, D.P.: The Territorial Expansion of the Cape Colony .... p 4.

23. HAINE, D.P.: The Territorial Expansion of the Cape Colony .... p 4.

24. LORIMER, E.K.: Fortified Farms and other Settler Homes (Looking Back, Maart 1963, p 8.)

25. LORIMER, E.K.: Fortified Farms ... (Looking Back, Maart 1963, p 9.)

26. LORIMER, E.K.: Fortified Farms ... (Looking Back, Maart 1963, p 10.)

27. LORIMER, E.K.: Fortified Farms ... (Looking Back, Maart 1963, p 10.)

28. LORIMER, E.K.: Addo Dritt and its Inns (Looking Back, Junie 1964. p 14.

29. HAINE, D.P.: The Territorial Expansion of the Cape Colony .... p 11.

30. HAINE, D.P.: The Territorial Expansion of the Cape Colony ..... p 11.

31. SCOT,, J.B.: Forts and Posts in the Eastern Cape (Looking Back, Sept. 1971, p 77).

32. SCOTT, J.B.: Forts and Posts ... (Looking Back, Sept. 1971, p 77).

33. SCOTT, J.B.: Forts and Posts ... (Looking Back, Sept. 1971, p 77).

34. SCOTT, J.B.: Forts and Posts ... (Looking Back, Sept. 1971, p 77).

35. ZIETSMAN, P.L.: Die Verdediging van, en Verdedigingsbeleid op die Oosgrens ...., p 3

36. HAINE, D.P.: The Territorial Expansion of the Cape Colony .... p 12

37. THERON, M.L.: Cradock's Place (Looking Back, Maart 1967, p 17).

38. ZIETSMAN, P.L.: Die Verdediging van, en Verdedigingsbeleid.... D 6

39. ZIETSMAN, P.L.: Die Verdediging van, en Verdedigingsbeleid ..., p 3.

40. ZIETSMAN, P.L.: Die Verdediging van, en Verdedigingsbeleid ...., 04.

41. HAINE, D.P.: The Territorial Expansion of the Cape Colony ...., p 13.

42. HAINE, D.P.: The Territorial Expansion of the Cape Colony .... p 15.

43. HAINE, D.P.: The Territorial Expansion of the Cape Colony .... p 16.

44. THEAL, G.M.: History of South Africa (1795-1834), p 144.

45. HOCKLY, H.E.: The Story of the British Settlers of 1820 in S.A., p 12

46. THEAL, G.M.: History of South Africa (1795-1834), p 145.

47. HOCKLY. H.E.: The Story of the British Settlers of 1820 in S.A., p 12.

48. SMITHERS, A.J.: The Kaffir Wars, 1779-1877, p 77.

49. ZIETSMAN, P.L.: Die Verdediging van, en Verdedigingsbeleid ..., p 33

50. SMITHERS, A.J.: The Kaffir Wars, $1779-1877$, p 78 .

51. HAINE, D.P.: The Territorial Expansion of the Cape Colony .... p 24

52. SMITHERS, A.J.: The Kaffir Wars, 1779-1877, p 78.

53. CORY, G.E.: The Rise of South Africa I, p 247.

54. SMITHERS, A.J.: The Kaffir Wars, 1779-1877, p 84-85.

55. HAINE, D.P.: The Territorial Expansion of the Cape Colony .... p 24. 
56. SMITHERS, A.J. The Kaffir Wars, 1779-1877, 87

57. HOCKLY, H.E.: The Story of the British Settlers in 1820 in S.A., p 14.

58. HAINE, D.P.: The Territorial Expansion of the Cape Colony ...., 25.

59. METROWICH, F.C.: Frontier Flames, p 29.

60. METROWICH, F.C.: Frontier Flames, p 251

61. CORY, G.E.: The Rise of South Africa I, p 251.

62. CORY, G.E.: The Rise of South Africa l, p 251.

63. CORY, G.E.: The Rise of South Africa I, p 252.

64. CORY, G.E.: The Rise of South Africa I, p 252.

65. CORY, G.E.: The Rise of South Africa I, p 252.

66. CORY, G.E.: The Rise of South Africa I, p 253.

67. CORY, G.E.: The Rise of South Africa I, p 253

68. SMITHERS, A.J.: The Kaffir Wars, $1779-1877$, p 88

69. CANNON, R.: Historical Records of the British Army, p 17.

70. THEAL, G.M.: History of South Africa $(1795-1834)$, p 174

71. SMITHERS, A.J.: The Kaffir Wars, 1779-1877, p 108.

72. THERON, M.L.: Eland's Post, Kaffir Dritt Post, Fort England (Grahamstown Historical Society, Annals 1973, I, no. 3).

73. SMITHERS, A.J.: The Kaffir Wars, 1779-1877, p 109.

74. CORY, G.E.: The Rise of South Africa I, p 302.

75. SMITHERS, A.J.: The Kaffir Wars, $1779-1877$, p 110.

76. HAINE, D.P.: The Territorial Expansion of the Cape Colony .... p 30.

77. CORY, G.E.: The Rise of South Africa I, p 308.

78. OBERHOLSTER, J.J.: Die Historiese Monumente van Suid-Afrika, p 152.

79. CORY, G.E.: The Rise of South Africa I, p 309.

80. POTGIETER, D.J.: Standard Encyclopaedia of Southern Africa IV, p 646.

81. OBERHOLSTER, J.J.: Die Historiese Monumente van Suid-Afrika, p 155.

82. KIRBY, P.R.: Fort Brown (Hermanuskraal) (Africana Notes ad News, Maart 1956, XII, no. I).

83. POTGIETER, D.J.: Standard Encyclopaedia of Southern Africa IV, p 646.

84. CORY, G.E.: The Rise of South Africa I, p 309.

85. CORY G.E: The Rise of South Africa I p 309

86. CORY, G.E.: The Rise of South Africa I, p 309

87. CORY, G.E.: The Rise of South Africa I, p 310

88. CORY, G.E.: The Rise of South Africa I, p 310.

89. OBERHOLSTER, J.J.: Die Historiese Monumente van Suid-Afrika, p 143 .

90. THEAL, G.M.: History of South Africa (1795-1834), p 212-213.

91. HAINE, D.P.: The Territorial Expansion of the Cape Colony ...., p 34

92. OBERHOLSTER, J.J.: Die Historiese Monumente van Suid-Afrika, P 144

93. HAINE, D.P.: The Territorial Expansion of the Cape Colony ..., p 35

94. HAINE, D.P.: The Territorial Expansion of the Cape Colony ...., p 38.

95. CORY, G.E.: The Rise of South Africa I, p 401-402.

96. POTGIETER, D.J.: Standard Encyclopaedia of Southern Africa IV, p 1.

97. DONALD, J.M.: Fort Peddie (Grahamstown Historical Society, 1971, I. no. $1, p 16)$

98. OBERHOLSTER, J.J.: Die Historiese Monumente van Suid-Atrika, D 165.

99. RANDLES, B.M.: Fort Willshire (Looking Back, Maart 1972, p 35)

100. BENYON, J: Fort Willshire (Grahamstown Historical Society, 1971, I, no. 1, p 17).

101. BENYON, J: Fort Willshire (Grahamstown Historical Society, 1971, I, no. $1, p$ 17).

102. RANDLES, B.M.: Fort Willshire (Looking Back, Maart 1972, p 35).

103. RANDLES, B.M.: Fort Willshire (Looking Back, Maart 1972, p 35)

104. OBERHOLSTER, J.J.: Die Historiese Monumente van Suid-Afrika, D 162

105. OBERHOLSTER, J.J.: Die Historiese Monumente van Suid-Afrika, p 152.

106. OBERHOLSTER, J.J.: Die Historiese Monumente van Suid-Afrika, p 156.

107. ENGELS, L.J..... D'Urban's Handling of the Frontier Problems ...., p 3

108. THERON, M.L.: Cradock's Place (Looking Back, Maart 1967, p 121).

109. THERON, M.L.: Eland's Post, Kaffir Dritt Post, Fort England (Grahamstown Historical Society, Annals 1973, I, no. 3, p 14).

110. HAINE, D.P.: The Territorial Expansion of the Cape Colony .... 60

111. ENGELS, L.J.:... D'Urban's Handling of the Frontier Problems .... p 7 .

112. ENGELS, L.J..... D'Urban's Handling of the Frontier Problems .... p 8.

113. SMITHERS, A.J.: The Kaffir Wars, 1779-1877, D 149.
114. HOCKLY, H.E.: The Story of the British Settlers in 1820 in S.A., p 152.

115. CORY, G.E.: The Rise of South Africa III, pD 77, 83, 89.

116. ENGELS, L.J.: ...D'Urban's Handling of the Frontier Problems ..., p 20.

117. ENGELS, L.J.: ... D'Urban's Handling of the Frontier Problems .... p 27.

118. HAINE, D.P.: The Territorial Expansion of the Cape Colony .... 66.

119. OBERHOLSTER, J.J.: Die Historiese Monumente van Suid-Afrika, D 155

120. OBERHOLSTER, J.J.: Die Historiese Monumente van Suid-Afrika, p 155.

121. POTGIETER, D.J.: Standard Encyclopaedia of Southern Africa IV, p 645.

122. OBERHOLSTER, J.J.: Die Historiese Monumente van Suid-Afrika, p 158.

123. POTGIETER, D.J.: Standard Encyclopaedia of Southern Africa IV, p 644

124. CORY, G.E.: The Rise of South Africa III, p 190.

125. CORY, G.E.: The Rise of South Africa III, p 190.

126. SCOTT, J.B.: Forts and Posts ... (Looking Back, Sept. 1971, p 84).

127. POTGIETER, D.J.: Standard Encyclopaedia of Southern Africa IV, p 654.

128. DONALD, J.M.: Fort Peddie (Grahamstown Historical Society, Annal 1973, I, no. 1, p 9)

129. CORY, G.E.: The Rise of South Africa III, p 187.

130. BURTON, A.W.: The Highlands of Kaffraria, D 31

131. WALSH, B.B.: Line Drift Post (Looking Back, Maart 1972, p 26)

132. CORY, G.E.: The Rise of South Africa III, p 190.

133. POTGIETER, D.J.: Standard Encyclopaedia of Southern Africa IV, p 659.

134. COETZEE, C.G.: Some Aspects of the Military History of Fort Hare and Fort Thompson (Looking Back, Sept. 1972, p 77).

135. CORY G.E. The Rise of South Africa III, p 185.

136. BURTON, A.W.: The Highlands of Kaffraria, p 30

137. CORY, G.E.: The Rise of South Africa III, p 186.

138. CORY, G.E.: The Rise of South Africa III, p 187.

139. BURTON, A.W.: The Highlands of Kaffraria, p 31

140. POTGIETER, D.J.: Standard Encyclopaedia of Southern Africa V. p 1.

141. RANDLES, B.M.: Fort Willshire (Looking Back, Maart 1972, p 25).

142. SCOTT, J.B.: Forts and Posts ... (Looking Back, Sept. 1971, D 84)

143. KLOTZ, W.: Fort Warden (Journal - Hist. Firearms .... Dec. 1973, VI, no. $4, p, 16)$.

144. KLOTZ, W.: Fort Warden (Journal - Hist. Firearms ..., Dec. 1973, VI, ก0. $4, p$ 18).

145. POTGIETER, D.J. (ed): Standard Encyclopaedia of Southern Africa V p 656 .

146. CORY, G.E.: The Rise of South Africa III, pp 145-146

147. CORY, G.E.: The Rise of South Africa III, p 168

148. POTGIETER, D.J. (ed): Standard Encyclopaedia of Southern Africa V, p 1.

149. POTGIETER, D.J. (ed): Standard Encyclopaedia of Southern Africa IV p 659 .

150. LEWIS, It-kol: Reports upon the Eastern Frontier .... p 48.

151. SCOTT, J.B.: Forts and Posts ... (Looking Back, Sept. 1971, p 78).

152. METROWICH, F.C.: Frontier Flames, p 96.

153. METROWICH, F.C.: Frontier Flames, p 96.

154. CORY, G.E.: The Rise of South Africa I, p 253.

155. CORY, G.E.: The Rise of South Africa I, p 312.

156. SMITHERS, A.J.: The Kaffir Wars, $1779-1877$, p 111

157. CORY, G.E.: The Rise of South Africa III, p 89

158. CORY, G.E.: The Rise of South Africa I, pp 250 en 252.

159. CORY, G.E.: The Rise of South Africa III, p 93.

160. CORY, G.E.: The Rise of South Africa I, p 252

161. CORY, G.E.: The Rise of South Africa I, p 310

162. SMITHERS, A.J.: The Kaffir Wars, 1779-1877, p 109

163. CORY, G.E.: The Rise of South Africa III, p 229.

164. CORY, G.E.: The Rise of South Africa III, pp 168 en 187

165. POTGIETER, D.J.: Standard Encyclopaedia of Southern Africa IV, p 656

166. CORY, G.E: The Rise of South Africa III. p 190

167. CORY, G.E.: The Rise of South Africa III, p 182

168. CORY, G.E.: The Rise of South Africa III, p 186.

169. POTGIETER, D.J.: Standard Encyclopaedia of Southern Africa V p 1

170. OBERHOLSTER, J.J.: Die Historiese Monumente van Suid-Atrika, p 162.

171. SMITHERS, A.J.: The Kaffir Wars, 1779-1877, pp 117 en 118. 